\title{
Umbilical cord blood stem cells transplantation as an adjunctive treatment strategy for liver cirrhosis in Chinese population: a meta-analysis of effectiveness and safety
}

This article was published in the following Dove Press journal:

Therapeutics and Clinical Risk Management

\author{
Huimin Tao $1, *$ \\ Yafeng $\mathrm{Li}^{1}$,* \\ Tingting Wang ${ }^{2}$ \\ Changhui Zhou ${ }^{3}$ \\ 'Department of Gastroenterology, \\ Liaocheng People's Hospital, \\ Liaocheng Clinical School of Taishan \\ Medical University, Liaocheng, \\ Shandong Province, People's Republic \\ of China; ${ }^{2}$ Department of Health Care, \\ Weifang People's Hospital, Weifang, \\ Shandong Province, People's Republic \\ of China; ${ }^{3}$ Department of Central \\ Laboratory, Liaocheng People's \\ Hospital, Liaocheng Clinical School of \\ Taishan Medical University, Liaocheng, \\ Shandong Province, People's Republic \\ of China
}

*These authors contributed equally to this work

\begin{abstract}
Objective: The aim of the study was to evaluate the efficacy and safety of umbilical cord blood stem cells (USCs) transplantation combined with routine supportive therapy (RST) for liver cirrhosis (LC).

Materials and methods: Clinical trials involved in this research were searched from Web of Science, PubMed, EMBASE, Cochrane Library, Wanfang and CNKI database. Treatment effects, quality of life (QoL), adverse events and other outcome measures were extracted and evaluated.
\end{abstract}

Results: A total of 10 trials including $616 \mathrm{LC}$ patients were involved in this study. Based on our analysis, the liver function of LC patients was significantly improved after USCs transplantation and RST combined therapy, indicated by decreased total bilirubin, alanine aminotransferase, aspartate aminotransferase levels and prothrombin time and increased serum albumin level and prothrombin activity. Compared to those treated by RST alone, patients treated by combined therapy showed more satisfied treatment effects, improved QoL reflected by improved appetite (odds ratio $[\mathrm{OR}]=5.43,95 \% \mathrm{CI}=2.84$ to $10.38, P<0.00001$ ) and relieved fatigue $(\mathrm{OR}=4.33$, $95 \% \mathrm{CI}=0.87$ to $21.60, P=0.07)$, ascetic fluid $(\mathrm{OR}=4.56,95 \% \mathrm{CI}=2.69$ to $7.74, P<0.00001)$, abdominal distension $(\mathrm{OR}=4.01,95 \% \mathrm{CI}=1.34$ to $12.02, P=0.01)$ and edema $(\mathrm{OR}=2.69,95 \%$ $\mathrm{CI}=0.23$ to $31.72, P=0.43$ ). No serious adverse events occurred during USCs therapy.

Conclusion: USCs transplantation is a safe and effective adjuvant therapy for RST-treated LC, possibly through improving patients' liver function.

Keywords: umbilical cord blood stem cells, routine supportive therapy, liver cirrhosis, metaanalysis

\section{Introduction}

Liver cirrhosis (LC) is a common chronic progressive liver disease with diffuse liver damage, which usually results from prolonged or repeated alcohol excess, viral hepatitis and other etiologies. ${ }^{1,2}$ LC is characterized as reduced liver regeneration and hepatic dysfunction, which can lead to portal hypertension with serious complications including ascites, hepatic encephalopathy, secondary infection and so on. ${ }^{3,4}$ Incidence of LC and mortality caused by LC had risen remarkably in the past few decades, and the patients were usually diagnosed at the irreversible state. ${ }^{1}$ Although survival has been improved due to effective LC management, it still ranks high among the world's leading causes of death. ${ }^{2,5}$ Liver transplantation is the only curative treatment for patients with decompensated LC, ${ }^{5}$ but it confronts with problems such as donor shortage,
Department of Central Laboratory Liaocheng People's Hospital, Liaocheng Clinical School of Taishan Medical University, Dongchang West Road, No 67, Liaocheng 252000, Shandong Province, People's Republic of China Tel +86 I35 62078772 Email zhouch2006@I63.com 
high medical costs, surgical complications, immunological rejection and ethical restraints. ${ }^{3,5}$ Liver transplantation failure may cause extensive and progressive fibrosis, which restrains liver regeneration and causes irreversible cirrhosis. ${ }^{3}$

Researchers have been exploring new approaches to promote liver regeneration, ${ }^{3}$ and stem cell therapy was considered as a promising treatment strategy. ${ }^{6,7}$ Preclinical LC studies on stem cell transplantation have shown beneficial effects, and the most commonly used cells were mesenchymal stem cells (MSCs), ${ }^{8-10}$ hepatic progenitor cells (HPCs) ${ }^{11,12}$ and hematopoietic stem cells (HSCs), ${ }^{13,14}$ which were usually obtained from autologous or allogeneic bone marrow., ${ }^{42}$ However, the procedure of bone marrow aspiration was invasive, and quantity and quality of bone marrow stem cells (BMSCs) are age-dependent, which limit their clinical potentiality. ${ }^{15-18}$ As an alternative source of BMSCs, umbilical cord blood stem cells (USCs) showed promising clinical application prospects. USCs are composed of immature immune cells and multipotent stem cells such as MSCs, endothelial progenitor cells (EPCs) and HSCs. ${ }^{16,17}$ They can migrate to injury sites due to chemotaxis, differentiate into various types of cells such as osteoblasts, chondrocytes and hepatocytes cells and secrete various cytokines and growth factors. ${ }^{19}$ Compared to BMSCs, USCs are more accessible with fewer ethical constraints. ${ }^{17,18,20}$

Clinical trials reported that USCs transfusion could ameliorate liver fibrosis and improve liver functions without significant side effects. ${ }^{21,22}$ In comparison with LC patients treated by routine supportive therapy (RST), those who underwent RST and USCs combined therapy exhibited more prominent therapeutic effects. In this study, we conducted a meta-analysis to systematically evaluate the therapeutic efficacy and safety of USCs and RST combined therapy in comparison with RST alone for LC, in order to provide scientific basis for future research and clinical application.

\section{Materials and methods}

\section{Search strategy and selection criteria}

We performed literature search across Web of Science, PubMed, EMBASE, Cochrane Library, Wanfang and CNKI database with key terms "stem cells" OR "umbilical cord blood stem cells", AND "liver cirrhosis" OR "hepatocirrhosis", without language restriction. Literature studies published before April 2017 were involved in this analysis.

The selection criteria are listed as follows: case-controlled trials involving > 30 LC patients; participants diagnosed with LC, without malignant tumor and not pregnant or lactating; patients in the experimental group who received USCs and RST combined therapy, and those in the control group who were treated by RST alone.

\section{Data extraction and quality assessment}

Two authors (Huimin Tao and Yafeng Li) collected and summarized data independently, including author's names, years of publication, locations, patients' ages and LC stages, samples sizes, causes of LC, therapeutic regimens, administration routes, number of USCs and study parameter types. Trials' quality was evaluated by following the instructions of Cochrane Handbook. ${ }^{23}$

\section{Outcome definition}

Clinical responses evaluated in this research included treatment efficacy, quality of life (QoL) and adverse events. Treatment efficacy was assessed in terms of levels of total bilirubin (TBIL), serum albumin (ALB), alanine aminotransferase (ALT), aspartate aminotransferase (AST), prothrombin time (PT), prothrombin activity (PTA) and Child-Pugh score. Patients' QoL covered the following indicators: fatigue, appetite, abdominal distension, ascitic fluid and edema.

\section{Statistical analysis}

We performed analysis using Review Manager 5.2 (Cochrane Collaboration). $P<0.05$ indicates differences with statistical significance. Appropriate analysis model was determined by heterogeneity according to Cochran's $Q$ test. ${ }^{24}$ Studies with $I^{2}<50 \%$ or $P>0.1$ was considered homogenous, and fixed-effects model was applied; otherwise a random-effects model was applied. ${ }^{25}$ Therapeutic efficacy was evaluated by odds ratio (OR) and presented with 95\% CI.

Publication bias was evaluated based on the funnel plot. Sensitivity analyses were also performed to assess the impact of number of infused cells $\left(>1 \times 10^{8}\right.$ or $\left.<1 \times 10^{8}\right)$ and routes of cell administration (intravenous or hepatic artery infusion).

\section{Results}

\section{Search results}

A total of 5,323 articles were initially identified, and 5,227 were excluded due to the lack of clinical trials $(n=4,876)$, duplication and repetition $(\mathrm{n}=187)$ or were unrelated studies $(\mathrm{n}=164)$. After full-text assessment, 18 reviews or metaanalyses, 12 articles without control group, 48 studies without USCs transplantation and 8 with insufficient data were also excluded. After selection, 10 trials $^{26-35}$ with 616 LC patients were included in this meta-analysis (Figure 1).

\section{Characteristics of patients}

All trials that met our selection criteria were conducted in People's Republic of China. In total, 327 LC patients accepted USCs and RST combined therapy, and 289 patients were treated by RST alone. 


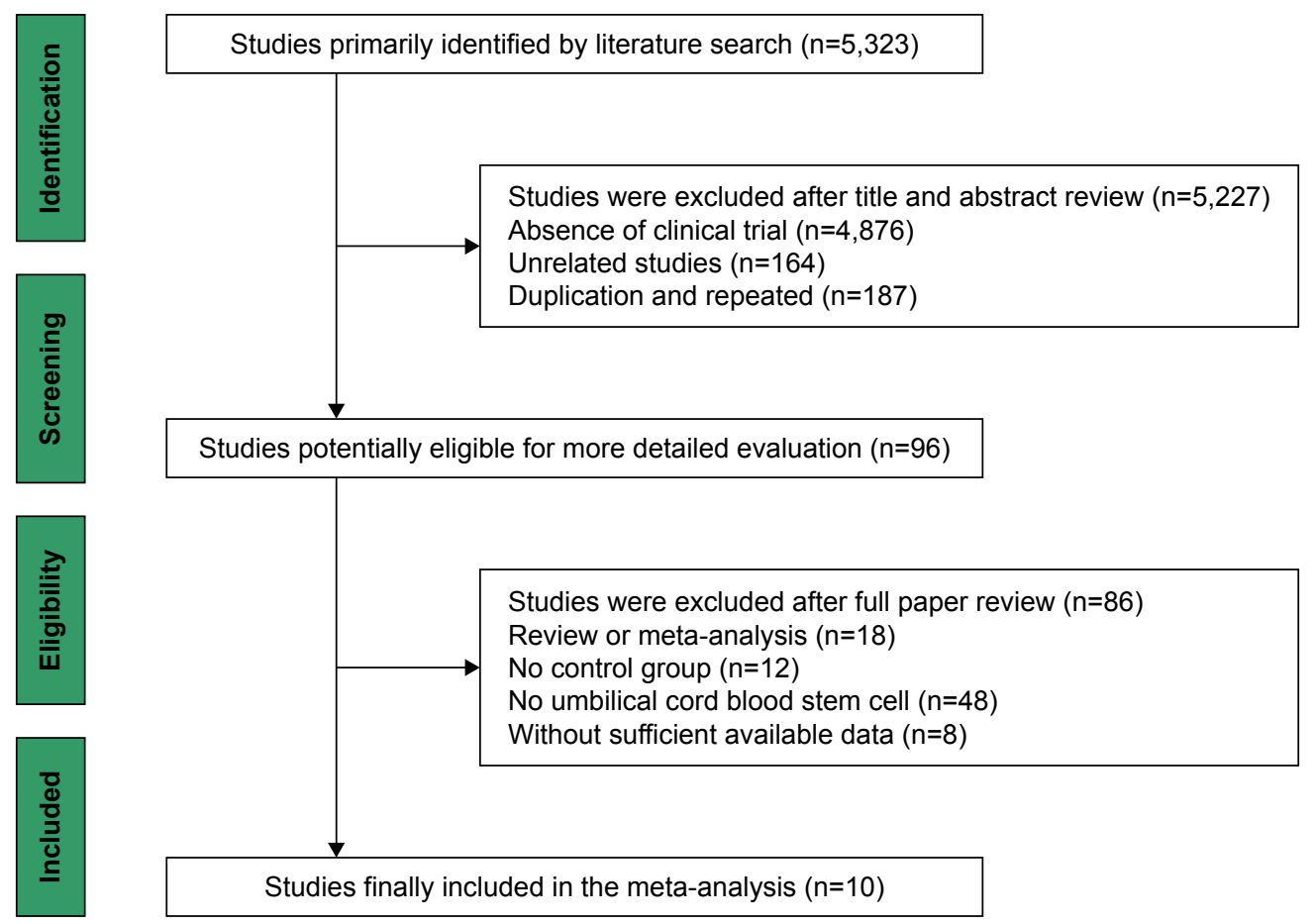

Figure I Flow diagram of the selection process.

USCs were obtained from healthy full-term infant's umbilical cord blood and were infused to LC patients through hepatic artery $(n=6)$, portal vein $(n=1)$ or peripheral vein $(n=3)$, respectively. Detailed information of the involved studies and participants is summarized in Tables 1 and 2 .

\section{Quality assessment}

Risk of bias assessment is shown in Figure 2. Six studies had low risk and the other 4 studies did not have clear description of randomization process. All studies had low risk of bias on allocation, performance and detection. One trial missing follow-up study and 1 trial missing primary outcome data had high risk of bias, and 2 studies with selective reporting had unclear risk of bias.

\section{Therapeutic efficacy assessments}

Random-effects meta-analysis was used to analyze the OR rate of the following descriptive indicators because of their high heterogeneity.

\section{Effectiveness of USCs on TBIL,ALB,ALT, AST and coagulation function}

As shown in Figure 3A, the TBIL level was reduced after combined therapy. This reduction was statistically significant

Table I Clinical information from the eligible trials in the meta-analysis

\begin{tabular}{|c|c|c|c|c|c|c|}
\hline \multirow[t]{2}{*}{ Included studies } & \multirow[t]{2}{*}{ Nation } & \multirow[t]{2}{*}{ Stage of LC } & \multirow{2}{*}{$\begin{array}{l}\text { No of } \\
\text { patients } \\
\text { Con/Exp }\end{array}$} & \multicolumn{2}{|l|}{ Age (years) } & \multirow[t]{2}{*}{ Causes of LC } \\
\hline & & & & Con & Exp & \\
\hline Li et al $(2013)^{26}$ & People's Republic of China & Child-Pugh C & $48 / 61$ & ND & ND & HBV \\
\hline Li and Zhang $(2016)^{27}$ & People's Republic of China & Child-Pugh A-C & $21 / 29$ & $19.2 \pm 5.3$ (mean) & $18.5 \pm 6.9$ (mean) & HDC \\
\hline Tan et al $(20 \mid 2)^{28}$ & People's Republic of China & Child-Pugh A-C & $20 / 22$ & ND & 56 (mean) & ND \\
\hline Wang et al $(2012)^{29}$ & People's Republic of China & Child-Pugh B-C & $31 / 30$ & $50 \pm 20$ (mean) & $48 \pm 22$ (mean) & $\begin{array}{l}\mathrm{HBV}(43), \mathrm{HCV}(13) \text { and } \\
\text { alcohol (5) }\end{array}$ \\
\hline Wang et al $(2014)^{30}$ & People's Republic of China & Child-Pugh B-C & $20 / 30$ & 52 (median) & 53 (median) & $\begin{array}{l}\text { HBV (35), HCV (5), } \\
\text { alcohol (6) and BC (4) }\end{array}$ \\
\hline Zhang et al $(2015)^{31}$ & People's Republic of China & Child-Pugh A-C & $23 / 25$ & $56.1 \pm 9.5$ (mean) & $55.6 \pm 10.7$ (mean) & HBV \\
\hline Zhou et al $(2013)^{32}$ & People's Republic of China & Child-Pugh B-C & $26 / 30$ & $42.8 \pm 5.1$ (mean) & $44.1 \pm 3.9$ (mean) & HBV \\
\hline Zhou et al $(2016)^{33}$ & People's Republic of China & Child-Pugh B-C & $30 / 30$ & $46 \pm 25$ (mean) & $45 \pm 26$ (mean) & $\mathrm{PBC}$ \\
\hline Zhou et al $(2017)^{34}$ & People's Republic of China & Child-Pugh B-C & $40 / 40$ & ND & ND & Alcohol \\
\hline Zhu and $\operatorname{Han}(2014)^{35}$ & People's Republic of China & Child-Pugh B-C & $30 / 30$ & $55.2 \pm 14.1$ (mean) & $54.3 \pm 12.4$ (mean) & PC (49) and alcohol (II) \\
\hline
\end{tabular}

Notes: Con, control group (RST alone group); Exp, experimental group (RST plus USCs therapy).

Abbreviations: LC, liver cirrhosis; ND, non-determined; HBV, hepatitis B virus; HDC, hepatolenticular degeneration cirrhosis; HCV, hepatitis C virus; PBC, primary biliary cirrhosis; BC, biliary cirrhosis; PC, post-hepatitic cirrhosis; RST, routine supportive treatment; USCs, umbilical cord blood stem cells. 
Table 2 Information of USCs therapy

\begin{tabular}{|c|c|c|c|c|c|}
\hline \multirow[t]{2}{*}{ Included studies } & \multicolumn{2}{|c|}{ Therapeutic regimen } & \multirow{2}{*}{$\begin{array}{l}\text { Administration } \\
\text { route }\end{array}$} & \multirow[t]{2}{*}{ Cell dose } & \multirow[t]{2}{*}{ Parameter types } \\
\hline & Exp group & Con group & & & \\
\hline Li et al $(2013)^{26}$ & Con Reg + USCs & RST & $1 \times 10^{9}$ & $1 \times 10^{9}$ & TBIL, ALT, PT and QoL \\
\hline $\mathrm{Li}$ and Zhang $(2016)^{27}$ & Con Reg + USCs & RST & $1.6-7.3 \times 10^{7}$ & $1.6-7.3 \times 10^{7}$ & TBIL, ALB, ALT, AST and PT \\
\hline Tan et al $(2012)^{28}$ & Con Reg + USCs & RST & $3.3 \times 10^{8}$ to $8.7 \times 10^{9}$ & $3.3 \times 10^{8}$ to $8.7 \times 10^{9}$ & TBIL, ALB, ALT and PT \\
\hline Wang et al $(2012)^{29}$ & Con Reg + USCs & RST & $1-5 \times 10^{7}$ & $1-5 \times 10^{7}$ & TBIL, ALB, ALT, AST and PTA \\
\hline Wang et al $(2014)^{30}$ & Con Reg + USCs & RST & $1.6-7.3 \times 10^{9}$ & $1.6-7.3 \times 10^{9}$ & TBIL, ALB, ALT, AST and PTA \\
\hline Zhang et al $(2015)^{31}$ & Con Reg + USCs & RST & $0.2-2 \times 10^{7}$ & $0.2-2 \times 10^{7}$ & TBIL, ALT, AST and PT \\
\hline Zhou et al $(2013)^{32}$ & Con Reg + USCs & RST & $>2 \times 10^{9}$ & $>2 \times 10^{9}$ & TBIL, ALB, ALT, AST, PT and QoL \\
\hline Zhou et al $(2016)^{33}$ & Con Reg + USCs & RST & $1-5 \times 10^{7}$ & $1-5 \times 10^{7}$ & TBIL, ALB, ALT, AST and PTA \\
\hline Zhou et al $(2017)^{34}$ & Con Reg + USCs & RST & $1-5 \times 10^{7}$ & $1-5 \times 10^{7}$ & TBIL, ALB, ALT, AST and PTA \\
\hline Zhu and Han $(2014)^{35}$ & Con Reg + USCs & RST & $1.7-7.5 \times 10^{7}$ & $1.7-7.5 \times 10^{7}$ & TBIL, ALB, ALT, PT and QoL \\
\hline
\end{tabular}

Notes: Con, control group (RST alone group); Exp, experimental group (RST plus USCs therapy).

Abbreviations: Con Reg, Control group regimen; USCs, umbilical cord blood stem cells; RST, routine supportive treatment; TBIL, total bilirubin; ALT, alanine aminotransferase; PT, prothrombin time; QoL, quality of life; ALB, albumin; AST, aspartate aminotransferase; PTA, prothrombin activity.

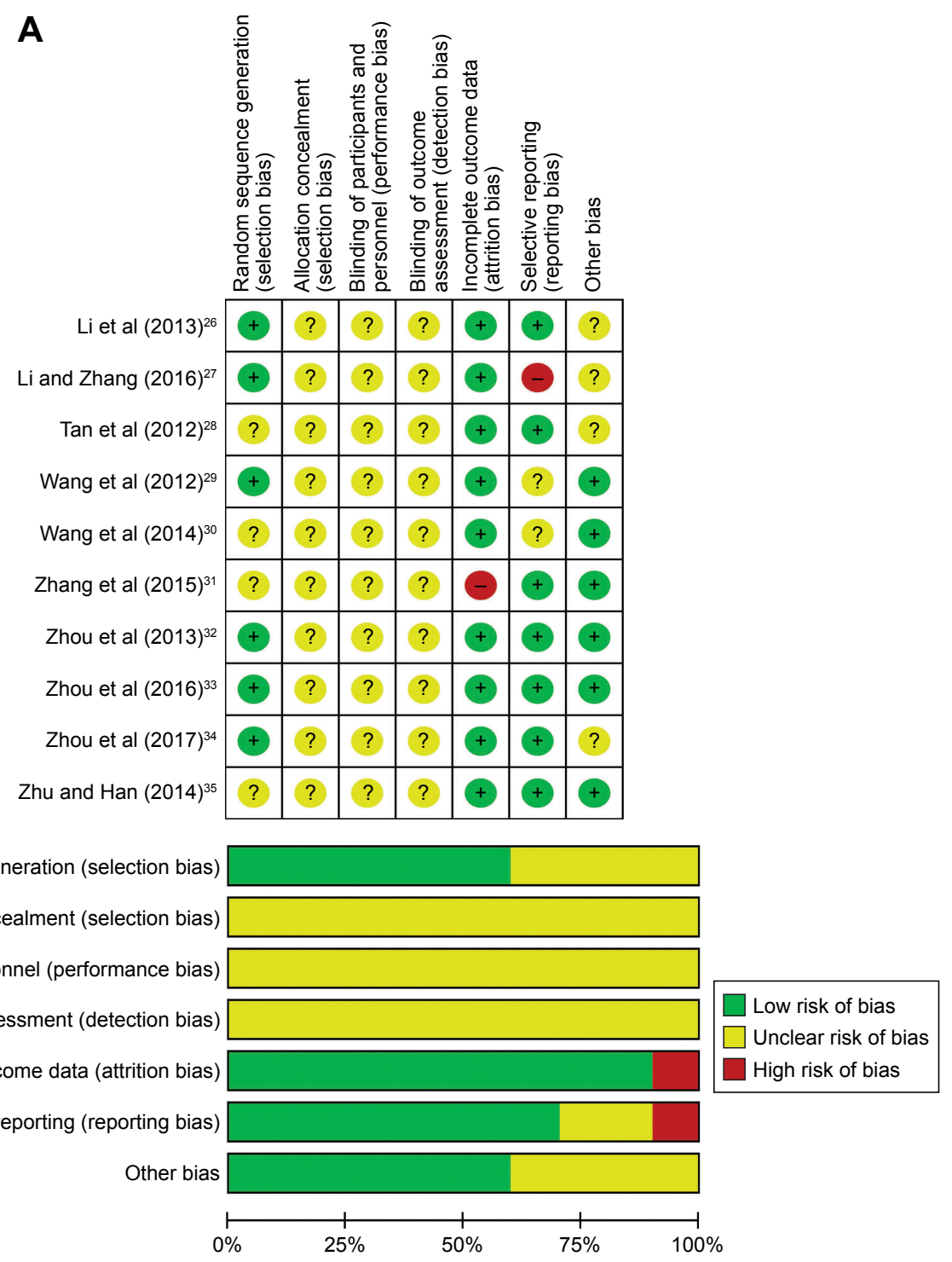

Figure 2 (A) Risk of bias summary: review of authors' judgments about each risk of bias item for the included studies. (B) Risk of bias graph: review of authors' judgments about each risk of bias item presented as percentages across all the included studies. Each color represents a different level of bias: red for high risk, green for low risk and yellow for unclear risk of bias. 


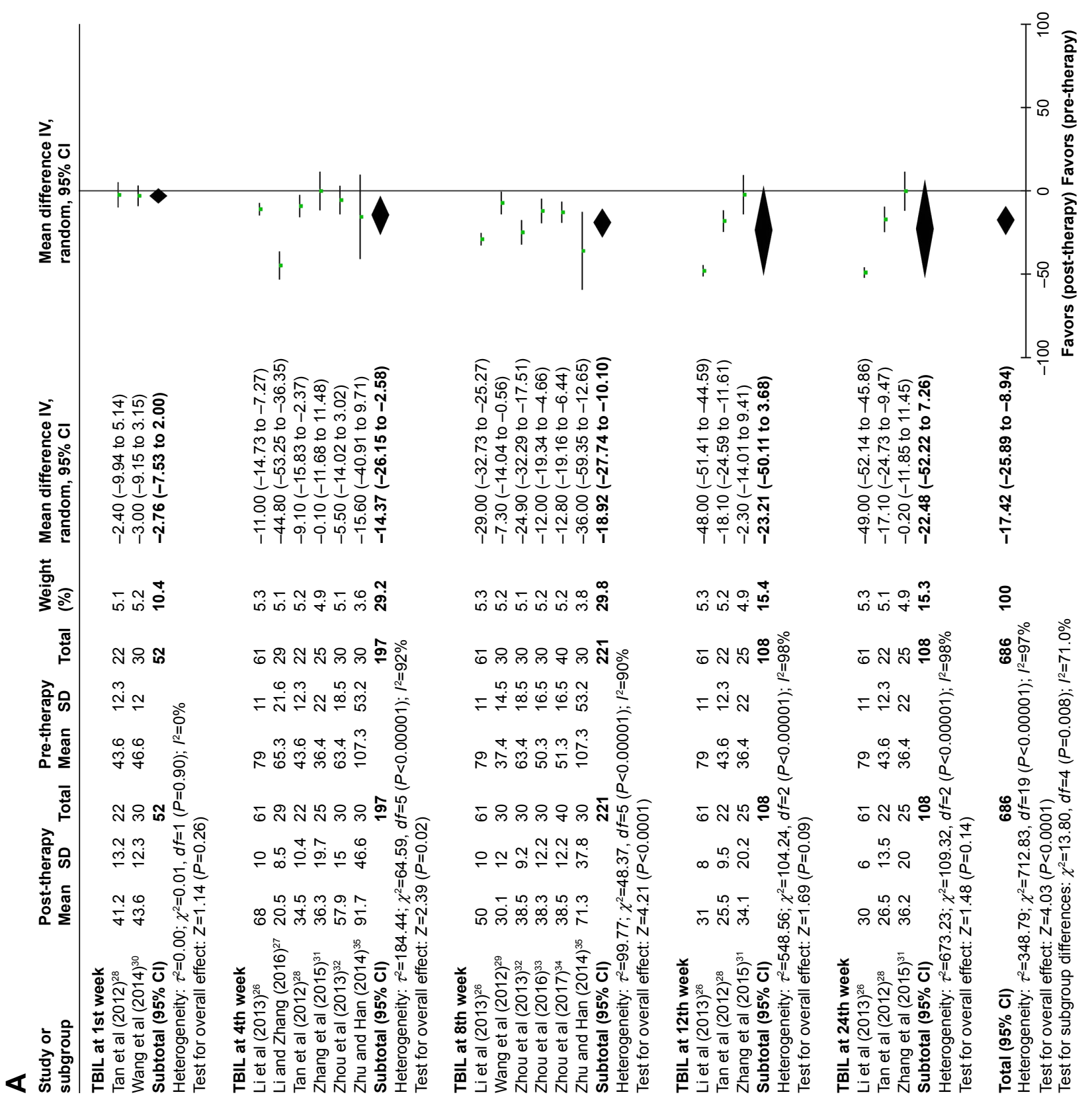




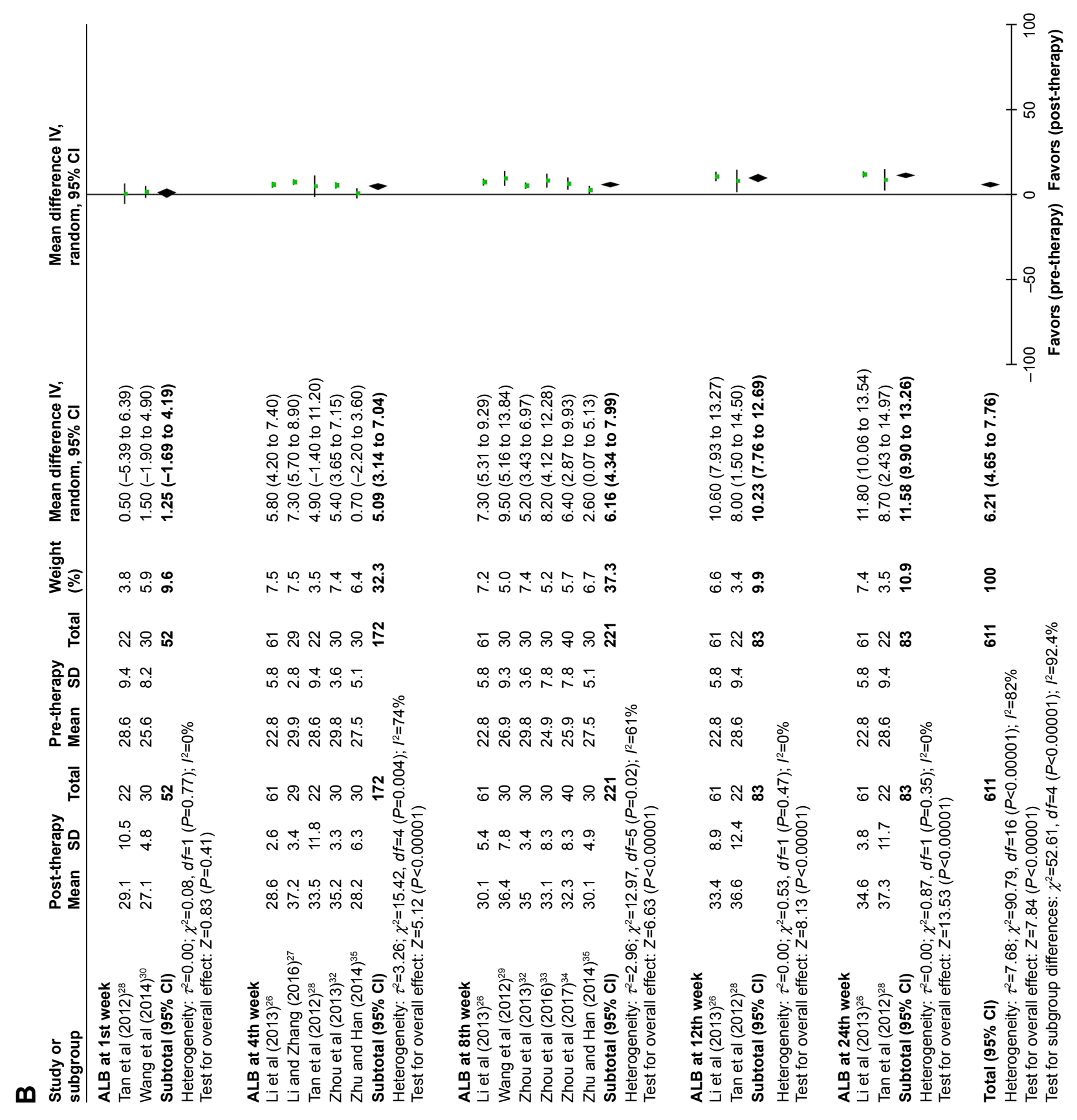




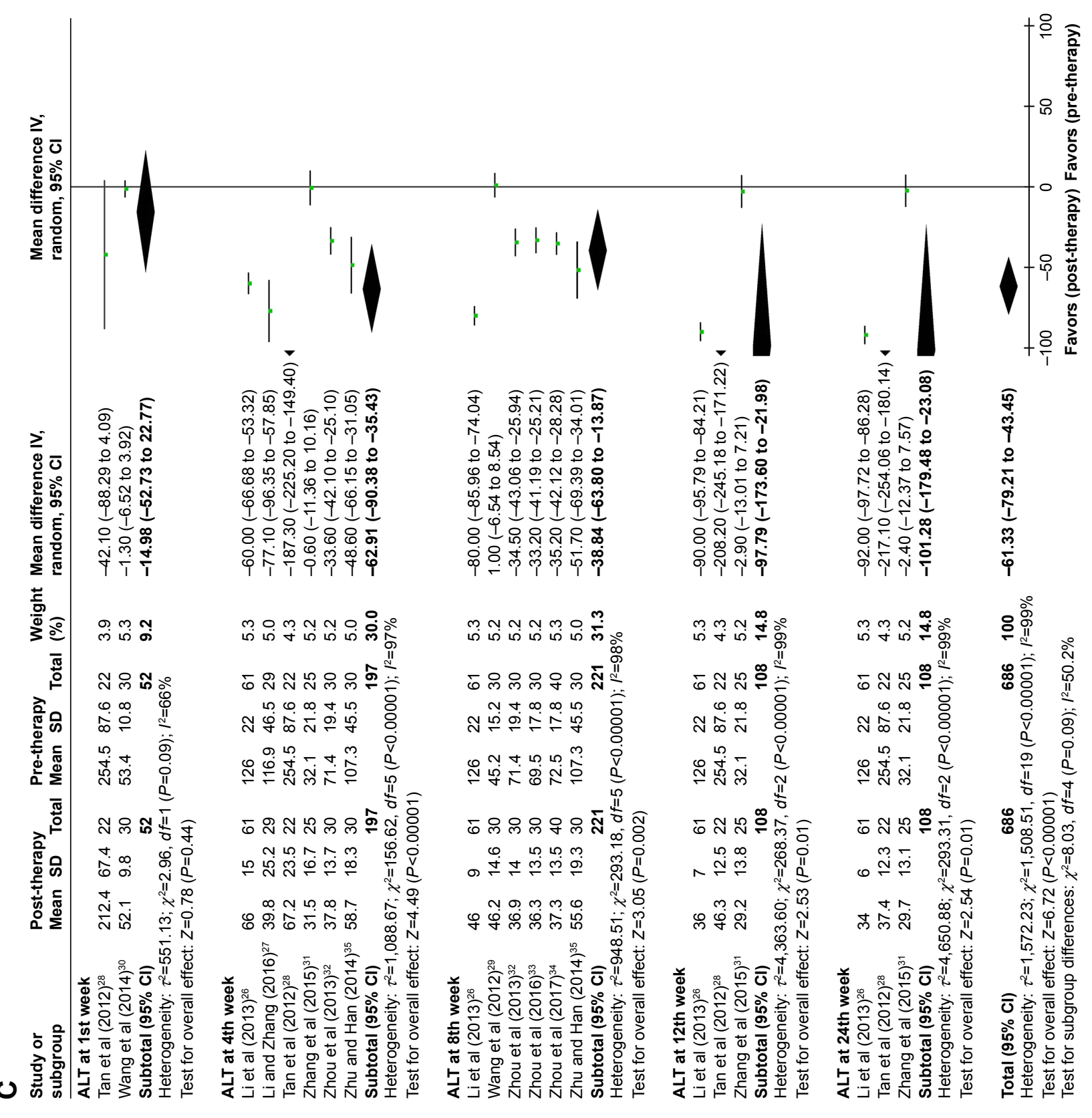




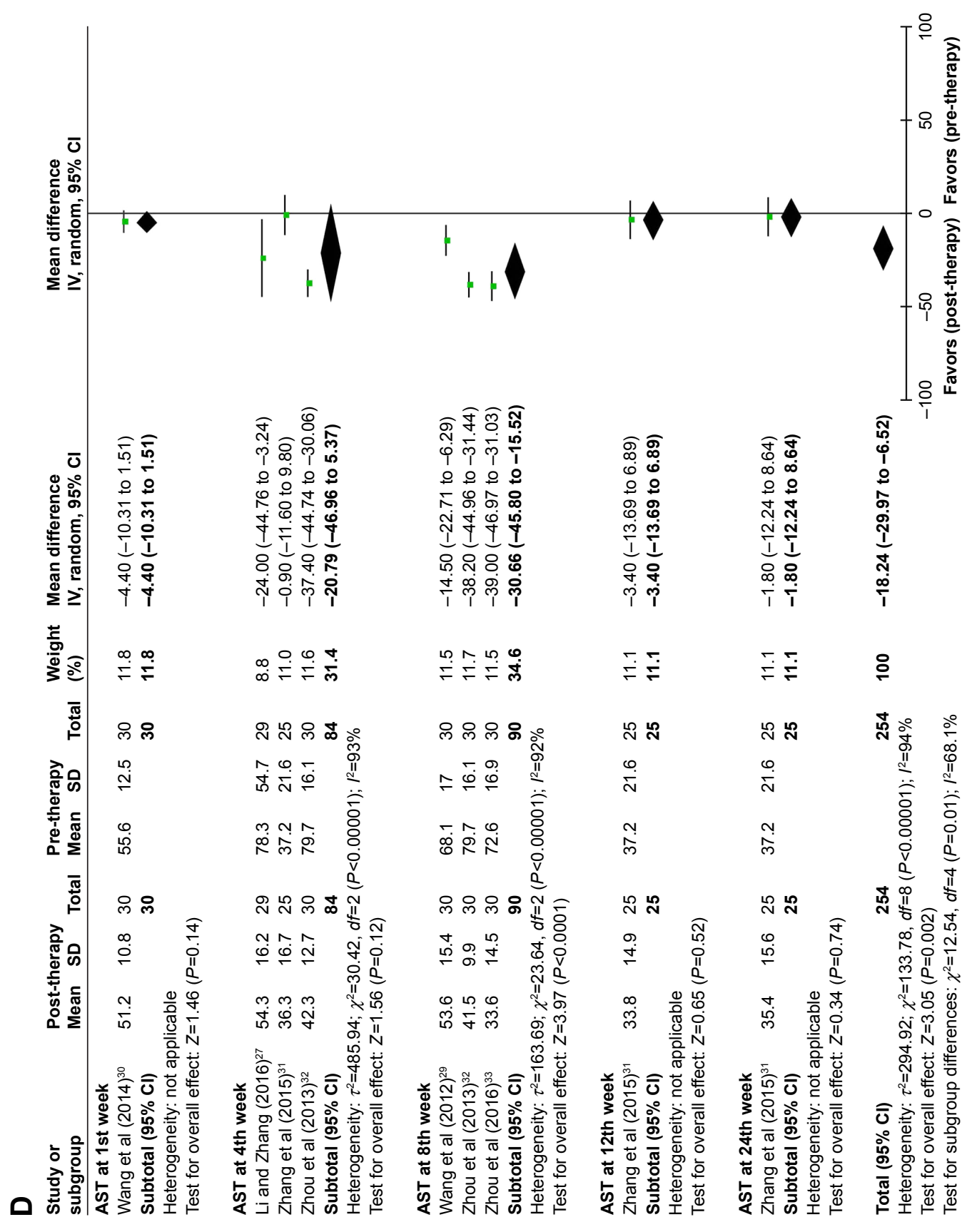

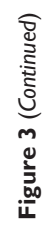




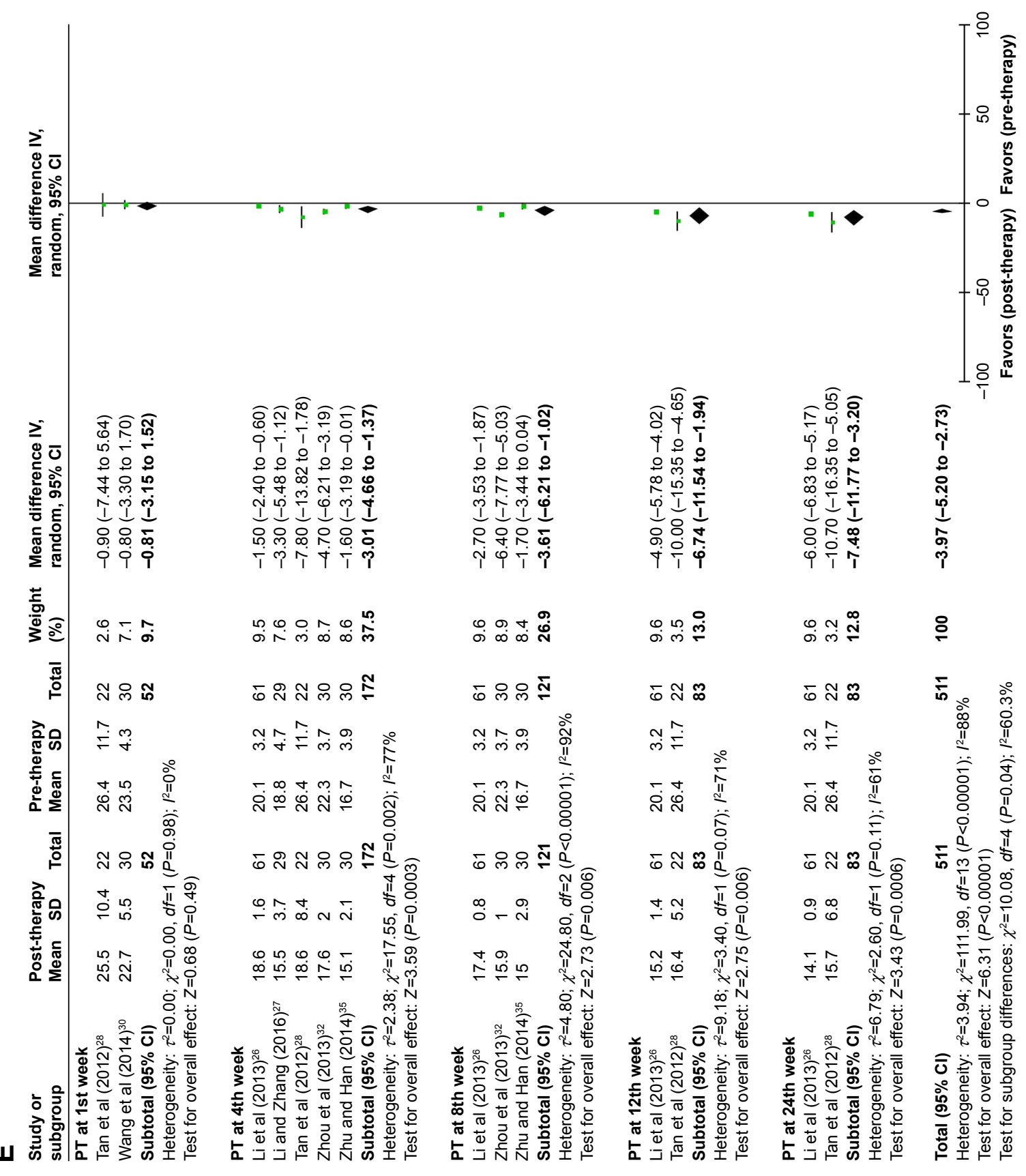




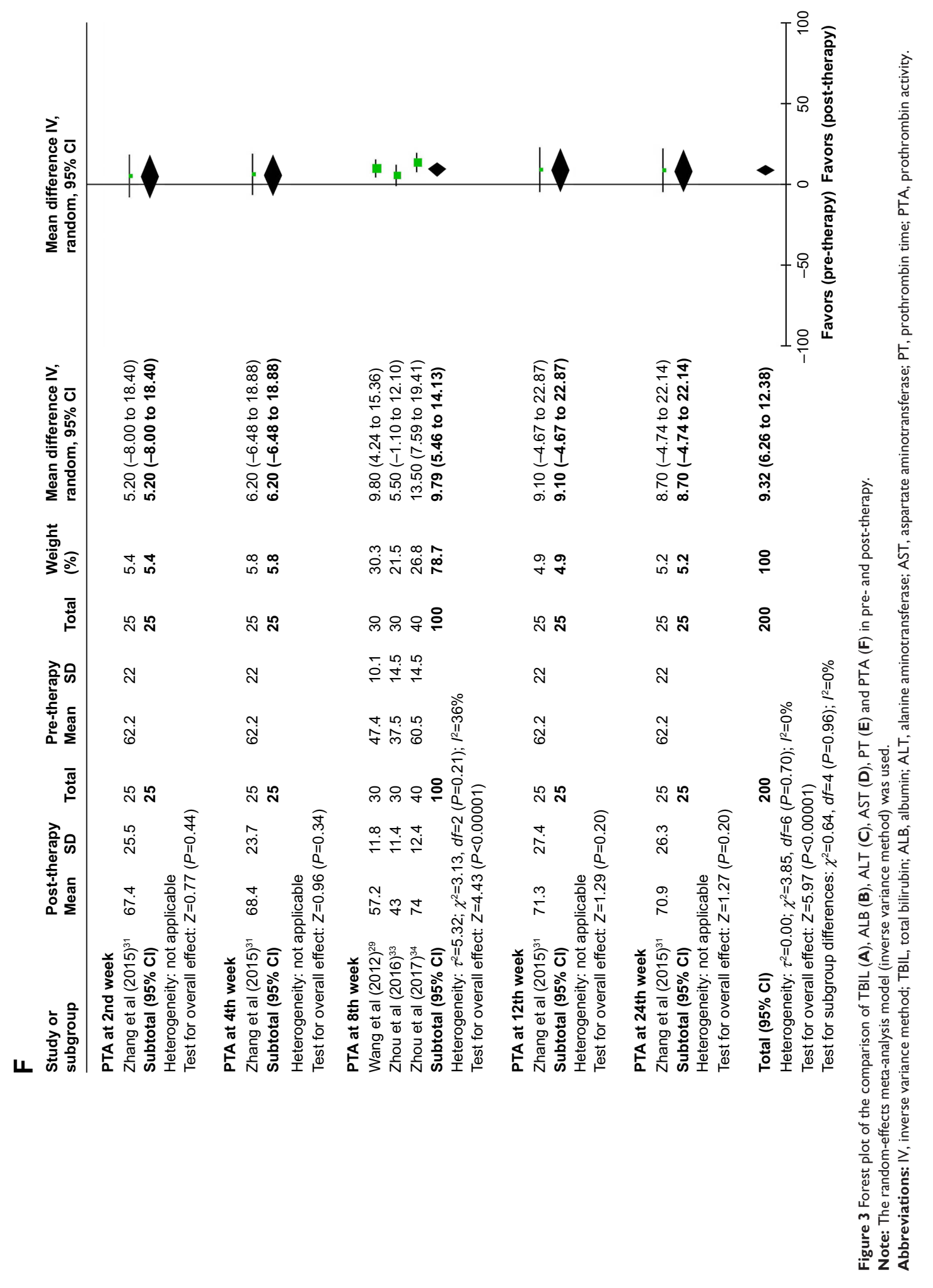


in the 4th and 8th week (4th: $O R=-14.37, C I=-26.15$ to $-2.58, P=0.02 ; 8$ th: $\mathrm{OR}=-18.92, \mathrm{CI}=-27.74$ to -10.10 , $P<0.0001)$, but not in the 1 st, 12 th and 24 th week after treatment ( $1 \mathrm{st}: \mathrm{OR}=-2.76, \mathrm{CI}=-7.53$ to $2.00, P=0.26 ; 12$ th: $\mathrm{OR}=-23.21, \mathrm{CI}=-50.11$ to $3.68, P=0.09 ; 24$ th: $\mathrm{OR}=-22.48$, $\mathrm{CI}=-52.22$ to $7.26, P=0.14)$. No statistical differences were observed in the TBIL level between experimental and control groups (Figure S1A).

The ALB level was increased after combined therapy, especially in the 4th, 8th, 12th and 24th week (Figure 3B, 1st: $\mathrm{OR}=1.25, \mathrm{CI}=-1.69$ to $4.19, P=0.41 ; 4$ th: $\mathrm{OR}=5.09, \mathrm{CI}=3.14$ to $7.04, P<0.00001 ; 8$ th: $\mathrm{OR}=6.16, \mathrm{CI}=4.34$ to 7.99 , $P<0.00001 ; 12$ th: $\mathrm{OR}=10.23, \mathrm{CI}=7.76$ to $12.69, P<0.00001$; 24th: $\mathrm{OR}=11.58, \mathrm{CI}=9.90$ to $13.26, P<0.00001)$. The ALB level in the combined therapy group was also higher than that of the control group in the 4th, 8th, 12th and 24th week after therapy (Figure S1B).

After combined therapy, the ALT level was significantly reduced in the 4th and 8 th week (Figure $3 \mathrm{C}, 1 \mathrm{st}$ : $\mathrm{OR}=-14.98$, $\mathrm{CI}=-52.73$ to $22.77, P=0.44 ; 4$ th: $\mathrm{OR}=-62.91, \mathrm{CI}=-90.38$ to $-35.43, P<0.00001 ; 8$ th: $\mathrm{OR}=-38.84, \mathrm{CI}=-63.80$ to $-13.87, P=0.002 ; 12$ th: $\mathrm{OR}=-97.79, \mathrm{CI}=-173.60$ to -21.98 , $P=0.01 ; 24$ th: $\mathrm{OR}=-101.28, \mathrm{CI}=-179.48$ to $-23.08, P=0.01)$. No statistical differences were observed in the ALT level between the 2 groups (Figure S1C).

As shown in Figure 3D, the AST level was significantly reduced only in the 8 th week after combined therapy (1st: $\mathrm{OR}=-4.40, \mathrm{CI}=-10.31$ to $1.51, P=0.14 ; 4$ th: $\mathrm{OR}=-20.79$, $\mathrm{CI}=-46.96$ to $5.37, P=0.12 ; 8$ th: $\mathrm{OR}=-30.66, \mathrm{CI}=-45.80$ to $-15.52, P<0.0001 ; 12$ th: $\mathrm{OR}=-3.40, \mathrm{CI}=-13.69$ to 6.89 , $P=0.52 ; 24$ th: $\mathrm{OR}=-1.80, \mathrm{CI}=-12.24$ to $8.64, P=0.74)$. Comparison between the 2 groups indicated that the AST level significantly decreased in the 8th week in the combined therapy group (Figure S1D).

The blood coagulation was evaluated in terms of PT and PTA. After combined therapy, PT was reduced in the 4 th, 8th, 12th and 24th week (Figure 3E, 1st: $\mathrm{OR}=-0.81$, $\mathrm{CI}=-3.15$ to $1.52, P=0.49 ; 4$ th: $\mathrm{OR}=-3.01, \mathrm{CI}=-4.66$ to $-1.37, P=0.0003 ; 8$ th: $\mathrm{OR}=-3.61, \mathrm{CI}=-6.21$ to -1.02 , $P=0.006 ; 12$ th: $\mathrm{OR}=-6.74, \mathrm{CI}=-11.54$ to $-1.94, P=0.006$; 24th: $\mathrm{OR}=-7.48, \mathrm{CI}=-11.77$ to $-3.20, P=0.0006)$. Compared with patients treated by RST alone, shorter PT were observed in combined therapy-treated patients in the 8th, 12th and 24th week after treatment (Figure S1E).

As shown in Figure 3F, in the 8th week after combined therapy, PTA was statistically increased (2nd: $\mathrm{OR}=5.20$, $\mathrm{CI}=-8.00$ to $18.40, P=0.44 ; 4$ th: $\mathrm{OR}=6.20, \mathrm{CI}=-6.48$ to $18.88, P=0.34$; 8 th: $\mathrm{OR}=9.79, \mathrm{CI}=5.46$ to $14.13, P<0.00001$; 12th: $\mathrm{OR}=9.10, \mathrm{CI}=-4.67$ to $22.87, P=0.20 ; 24$ th: $\mathrm{OR}=8.70$, $\mathrm{CI}=-4.74$ to $22.14, P=0.20)$. Meanwhile, the pooled results showed that in the 8 th week after treatment, patients who underwent combined therapy had more significantly increased PTA compared with patients who received RST alone (Figure S1F).

All the abovementioned results indicated that the combination of USCs and RST had better therapeutic effects for LC patients than RST alone.

\section{QoL assessment}

QoL of patients who received combined therapy was significantly improved compared to those treated by RST alone, indicated by better appetite, relieved ascitic fluid and abdominal distension after USCs treatment (Figure 4, appetite: $\mathrm{OR}=5.43, \mathrm{CI}=2.84$ to $10.38, P<0.00001$; ascitic fluid: $\mathrm{OR}=4.56, \mathrm{CI}=2.69$ to $7.74, P<0.00001$; abdominal distension: $\mathrm{OR}=4.01, \mathrm{CI}=1.34$ to $12.02, P=0.01$ ), whereas the improvements in fatigue and edema were not significant (Figure 4, fatigue: $\mathrm{OR}=4.33, \mathrm{CI}=0.87$ to $21.60, P=0.07$; edema: $\mathrm{OR}=2.69, \mathrm{CI}=0.23$ to $31.72, P=0.43$ ). Appetite and ascitic fluid were not heterogeneous among the studies, so the fixed-effects model was used for analyzing their OR. Otherwise, random-effects model was used.

\section{Adverse events assessment}

We evaluated safety of USCs therapy in this meta-analysis. The most common side effect during treatment was fever, which usually subsided within 24 hours without treatment. No serious adverse events or death were reported after USCs therapy (Table 3). However, all trials did not compare the incidence of side effects in experimental and control groups.

\section{Publication bias}

Funnel plots of TBIL, ALB, ALT and PT data were symmetrical in general, indicating small publication bias (Figures 5 and S2).

\section{Sensitivity analysis}

Subgroup analyses were performed to evaluate the effects of cell numbers $\left(>1 \times 10^{8}\right.$ or $\left.<1 \times 10^{8}\right)$ and administration routes (through intravenous or hepatic artery) on clinical efficacy. Results showed that a larger number of infused USCs (cell numbers $>1 \times 10^{8}$ ) were associated with improved liver function, indicated by decreased TBIL and ALT levels and PT and increased ALB level (Tables 4 and S1). Moreover, compared to intravenous USCs perfusion, USCs transplantation 


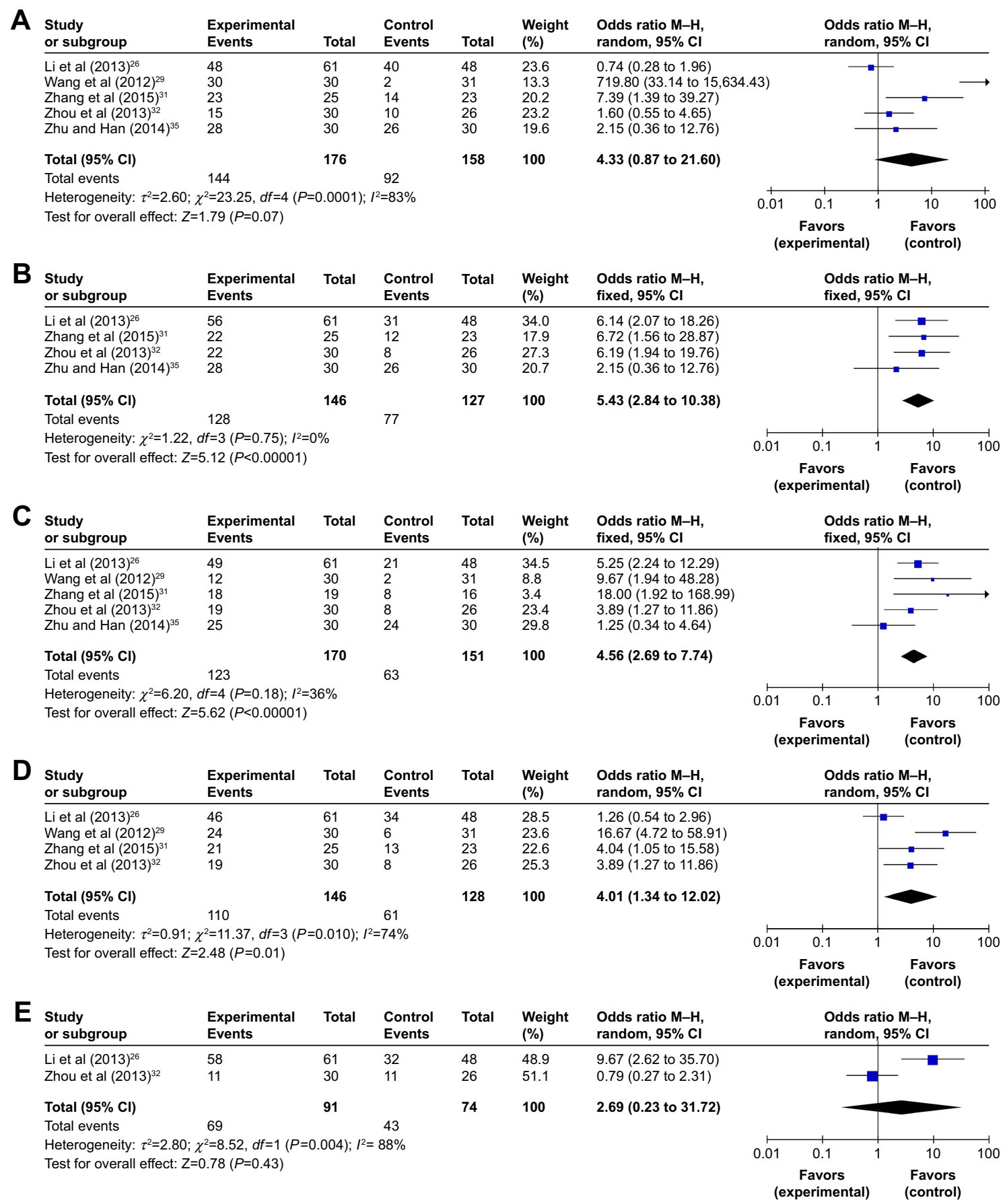

Figure 4 Forest plot of the comparison of QoL including fatigue (A), appetite (B), abdominal distension (C), ascitic fluid (D) and edema (E) between the experimental and control groups.

Notes: Control group, RST alone group; experimental group, RST plus USCs therapy.

Abbreviations: M-H, Mantel-Haenszel method; QoL, quality of life; USCs, umbilical cord blood stem cells; RST, routine supportive treatment.

through hepatic artery was more effective in reducing the TBIL level and PT, but less valid in increasing the ALB level (Tables 4 and S1).

\section{Discussion}

Stem cells derived from umbilical cord blood are mainly composed of HSCs, MSCs, EPCs and immature immunological cells. ${ }^{16} \mathrm{HSCs}$ and MSCs can differentiate into functional hepatocyte-like cells both in vitro and in vivo. ${ }^{36,37}$ Their anti-inflammatory and paracrine function can affect liver function. ${ }^{5}$ MSCs can migrate and home to injured liver tissue, ${ }^{38}$ differentiate into hepatocytes, inhibit hepatocytes death, ${ }^{39}$ stimulate endogenous hepatocyte regeneration and promote the secretion of HGF, epidermal growth factor 
Table 3 Information of adverse events during the USCs therapy

\begin{tabular}{ll}
\hline Included studies & Adverse events (number) \\
\hline Li et al $(2013)^{26}$ & $\begin{array}{l}\text { No obvious adverse reactions; } \\
\text { excitement (I2) }\end{array}$ \\
Li and Zhang $(2016)^{27}$ & Fever (I) \\
Tan et al $(2012)^{28}$ & No obvious adverse reactions \\
Wang et al $(2012)^{29}$ & No obvious adverse reactions \\
Wang et al $(2014)^{30}$ & No obvious adverse reactions \\
Zhang et al $(2015)^{31}$ & No obvious adverse reactions \\
Zhou et al $(2013)^{32}$ & No obvious adverse reactions; \\
& low-grade fever (3) \\
Zhou et al $(2016)^{33}$ & No obvious adverse reactions \\
Zhou et al $(2017)^{34}$ & No obvious adverse reactions \\
Zhu and Han $(2014)^{35}$ & Low-grade fever (I); tension, pain (I) \\
\hline
\end{tabular}

Abbreviation: USCs, umbilical cord blood stem cells.

(EGF) and vascular endothelial growth factor (VEGF), ${ }^{40}$ thereby enhance liver regeneration. van Poll et $\mathrm{al}^{39}$ and Parekkadan et $\mathrm{al}^{41}$ reported that MSCs can upregulate antiinflammatory cytokine IL-10 and downregulate pro-inflammatory cytokines such as TNF- $\alpha$ and IL-6, by which they alleviate liver fibrosis. Moreover, MSCs can alleviate cirrhosis through inhibiting hepatic stellate cells' proliferation, promoting their apoptosis and inhibiting extracellular matrix (ECM) accumulation. ${ }^{3,42,43}$ Research of Higashiyama et al ${ }^{44}$ indicated that MSCs can alleviate cirrhosis through expressing matrix metalloproteinase-2 (MMP-2) and MMP-9, which had antifibrotic effect by degrading the ECM. Pan et $\mathrm{al}^{45}$ demonstrated that MSCs can attenuate liver fibrosis by specifically downregulating Dlk-1 expression through FGF2 secretion. Chen et al ${ }^{46}$ found that MSCs remarkably inhibited the proliferation of hepatic stellate cells through activation of Notch and PI3K/Akt signaling pathways. EPCs have potential to regenerate the vascular endothelium in liver. ${ }^{5,47}$ Therefore, USCs were considered with promising prospective to treat $\mathrm{LC}$.

In recent years, several studies have shown that USCs were safe and feasible treatment for LC. However, the different clinical protocols among those studies may lead to different therapeutic effects. In this study, we investigated published clinical trials extensively to achieve high statistical reliability. Our meta-analysis revealed that compared to LC patients who received RST alone, those treated by USCs and RST combined therapy exhibited more favorable efficacy,
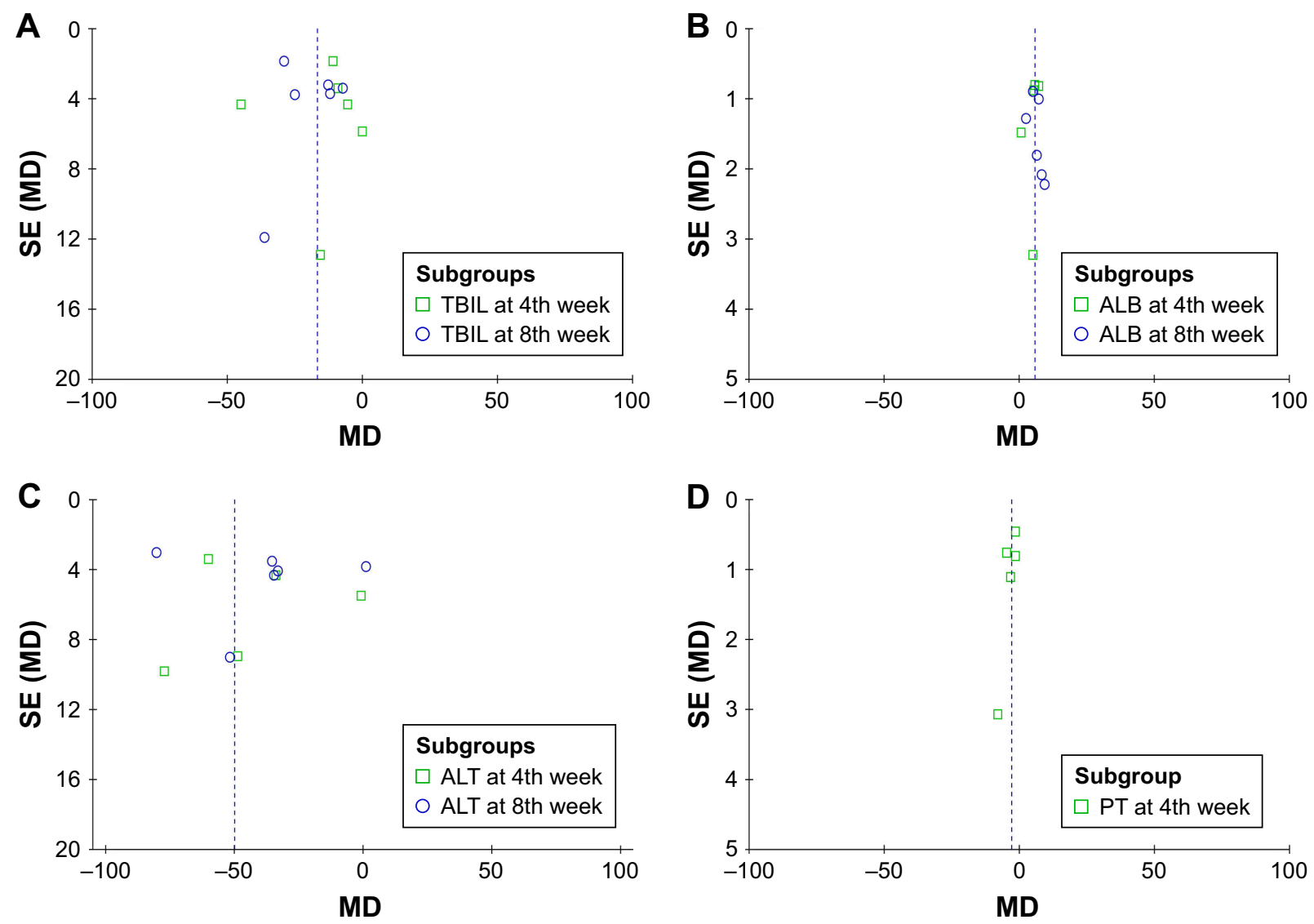

Figure 5 Funnel plot of percentage of TBIL (A), ALB (B), ALT (C) and PT (D) in pre- and post-therapy.

Note: Bias analyses were conducted for parameters discussed in $>6$ papers.

Abbreviations: TBIL, total bilirubin; ALB, albumin; ALT, alanine aminotransferase; PT, prothrombin time. 
Table 4 Subgroup analyses of TBIL, ALB, ALT and PT in pre- and post-therapy

\begin{tabular}{|c|c|c|c|c|c|c|c|c|c|c|}
\hline \multirow[t]{2}{*}{ Parameters } & \multirow{2}{*}{$\begin{array}{l}\text { Time point } \\
\text { (after } \\
\text { therapy) }\end{array}$} & \multirow{2}{*}{$\begin{array}{l}\text { Factors at } \\
\text { study level }\end{array}$} & \multirow{2}{*}{$\begin{array}{l}\text { Pre-therapy } \\
\text { No of } \\
\text { patients }\end{array}$} & \multirow{2}{*}{$\begin{array}{l}\text { Post-therapy } \\
\text { No of } \\
\text { patients }\end{array}$} & \multirow{2}{*}{$\begin{array}{l}\text { Analysis } \\
\text { method }\end{array}$} & \multicolumn{2}{|c|}{ Heterogeneity } & \multirow[t]{2}{*}{ OR } & \multirow[t]{2}{*}{$95 \% \mathrm{Cl}$} & \multirow[t]{2}{*}{$P$-value } \\
\hline & & & & & & $I^{2}(\%)$ & $P$-value & & & \\
\hline \multirow[t]{6}{*}{ TBIL } & 4th week & $\mathrm{CN}>1 \times 10^{8}$ & 113 & 113 & Random & 0 & 0.49 & -9.91 & -12.95 to -6.86 & $<0.00001$ \\
\hline & & $\mathrm{CN}<\mathrm{I} \times 10^{8}$ & 84 & 84 & Random & 95 & $<0.00001$ & -20.56 & -53.73 to $\mid 2.6 \mathrm{I}$ & 0.22 \\
\hline & & Hepatic artery & 82 & 82 & Random & 0 & 0.68 & -8.05 & -13.22 to -2.88 & 0.002 \\
\hline & & Intravenous & 115 & 115 & Random & 97 & $<0.0000 \mathrm{I}$ & -18.77 & -42.39 to 4.85 & 0.12 \\
\hline & 8th week & $\mathrm{CN}>\mathrm{I} \times 10^{8}$ & 91 & 91 & Random & 0 & 0.33 & -28.17 & -31.50 to -24.84 & $<0.00001$ \\
\hline & & $\mathrm{CN}<\mathrm{I} \times 10^{8}$ & 130 & 130 & Random & 49 & 0.12 & -12.14 & $-18.0 \mid$ to -6.26 & $<0.0001$ \\
\hline \multirow[t]{6}{*}{ ALB } & 4th week & $\mathrm{CN}>\mathrm{I} \times 10^{8}$ & 113 & 113 & Random & 0 & 0.92 & 5.59 & 4.44 to 6.75 & $<0.00001$ \\
\hline & & $\mathrm{CN}<\mathrm{I} \times 10^{8}$ & 59 & 59 & Random & 93 & $<0.0001$ & 4.12 & -2.35 to 10.58 & 0.21 \\
\hline & & Hepatic artery & 82 & 82 & Random & 73 & 0.02 & 3.57 & 0.02 to 7.11 & 0.05 \\
\hline & & Intravenous & 90 & 90 & Random & 41 & 0.19 & 6.55 & 5.08 to 8.02 & $<0.00001$ \\
\hline & 8th week & $\mathrm{CN}>\mathrm{I} \times 10^{8}$ & 91 & 91 & Random & 58 & 0.12 & 6.20 & 4.14 to 8.26 & $<0.0000$ I \\
\hline & & $\mathrm{CN}<\mathrm{I} \times 10^{8}$ & 130 & 130 & Random & 71 & 0.02 & 6.37 & 3.10 to 9.64 & 0.0001 \\
\hline \multirow[t]{6}{*}{ ALT } & 4th week & $\mathrm{CN}>\mathrm{I} \times 10^{8}$ & 113 & 113 & Random & 97 & $<0.0000$ I & -84.81 & $-122.7 \mid$ to -46.90 & $<0.0001$ \\
\hline & & $\mathrm{CN}<\mathrm{I} \times 10^{8}$ & 84 & 84 & Random & 96 & $<0.0000$ I & -41.59 & -88.74 to 5.56 & 0.08 \\
\hline & & Hepatic artery & 82 & 82 & Random & 97 & $<0.0000$ I & -85.80 & -142.84 to -28.76 & 0.003 \\
\hline & & Intravenous & 115 & 115 & Random & 98 & $<0.0000 \mathrm{I}$ & -45.52 & -89.67 to -1.37 & 0.04 \\
\hline & 8th week & $\mathrm{CN}>\mathrm{I} \times 10^{8}$ & 91 & 91 & Random & 99 & $<0.00001$ & -57.36 & -101.95 to -12.77 & 0.01 \\
\hline & & $\mathrm{CN}<\mathrm{I} \times 10^{8}$ & 130 & 130 & Random & 96 & $<0.00001$ & -29.02 & -49.72 to -8.33 & 0.006 \\
\hline \multirow[t]{4}{*}{ PT } & 4th week & $\mathrm{CN}>\mathrm{I} \times 10^{8}$ & 113 & 113 & Random & 87 & 0.0003 & -3.81 & -6.82 to -0.80 & 0.01 \\
\hline & & $\mathrm{CN}<1 \times 10^{8}$ & 59 & 59 & Random & 35 & 0.22 & -2.28 & -3.91 to -0.65 & 0.006 \\
\hline & & Hepatic artery & 82 & 82 & Random & 80 & 0.007 & -3.88 & -6.75 to -1.00 & 0.008 \\
\hline & & Intravenous & 90 & 90 & Random & 55 & 0.13 & -2.12 & -3.79 to -0.44 & 0.01 \\
\hline
\end{tabular}

Note: Subgroup analyses were conducted in parameters discussed in $>6$ papers.

Abbreviations: CN, cell number; TBIL, total bilirubin; ALB, albumin; ALT, alanine aminotransferase; PT, prothrombin time; OR, odds ratio.

including increased ALB and PTA levels, and decreased TBIL, ALT, AST levels and PT, although changes in TBIL and ALT levels did not show statistical significance. Patients' QoL was remarkably improved after USCs therapy, including improved appetite and relieved fatigue, abdominal distension, ascitic fluid and edema. These results indicated that the combination of USCs transplantation and RST had more satisfied therapeutic effects for LC patients than those treated by RST alone.

USCs have been clinically applied to treat hematological malignancies for more than 2 decades with a good safety record. In this research, our analyses showed that USCs were also safe to treat LC. Fever was the most common side effect during USCs therapy, which in most cases resolved naturally, and no serious adverse events or death occurred during therapy.

Some factors may influence the therapeutic effects of USCs therapy, such as USCs dosages and infusion routes. Number of infused USCs is one of the primary determinations in therapeutic strategy optimization. Nakamura et al found that human $\mathrm{CD}_{4} 4^{+}$cell transplantation after chronic liver injury aroused functional regeneration in a dose-dependent manner..$^{48}$ Our analysis also revealed that a larger number of infused USCs were associated with more satisfied efficacy.
Moreover, we found that USCs infusion through hepatic artery was more effective in reducing TBIL and PT but not in increasing ALB compared to intravenous perfusion. However, currently available publications probing the impact of administration routes on USCs' curative effect are still insufficient, and more data will be needed to perform convincible statistical analysis. We expect our study will be valuable for the design of upcoming comprehensive clinical trials.

Our study has some limitations. The numbers of LC patients included in this study was not big enough and the follow up periods was short. Although the effectiveness of USCs therapy on hematological, nerve and other system diseases have been reported, ${ }^{49-52}$ but its application on LC was still mainly performed in People's Republic of China. This may be because there are a large number of Chinese LC patients and many Chinese research studies were focused on it, therefore abundant papers were generated. Moreover, the therapeutic effects of USCs therapy are affected by multiple factors, such as injection modes, infused USCs numbers and LC stages. Further detailed analyses need to be conducted based on research studies with sufficient information, standardized therapeutic regimens and strict patients inclusion criteria. Although the therapeutic effects of USCs for LC were satisfied, which 
population of cells among USCs was mainly responsible for these effects was unclear, and the underlying mechanism remained elusive. Qi et $\mathrm{al}^{5}$ assumed that the improved liver microenvironments and/or the increased hepatocytes number may help liver function recovery after stem cell therapy.

\section{Conclusion}

This study confirmed the efficacy and safety of USCs transplantation and RST combined therapy for LC patients. USCs therapy greatly enhanced the improvement in liver function after RST and improved QoL of LC patients. Therefore, USCs transplantation and RST combined therapy is a promising treatment option for LC patients.

\section{Acknowledgment}

Huimin Tao and Yafeng Li are the co-first authors.

\section{Author contributions}

All authors contributed toward data analysis, drafting and critically revising the paper and agree to be accountable for all aspects of the work.

\section{Disclosure}

The authors report no conflicts of interest in this work.

\section{References}

1. Irfan A, Ahmed I. Could stem cell therapy be the cure in liver cirrhosis? J Clin Exp Hepatol. 2015;5(2):142-146.

2. Than NN, Tomlinson CL, Haldar D, King AL, Moore D, Newsome PN. Clinical effectiveness of cell therapies in patients with chronic liver disease and acute-on-chronic liver failure: a systematic review protocol. Syst Rev. 2016;5:100.

3. Ma XR, Tang YL, Xuan M, Chang Z, Wang XY, Liang XH. Transplantation of autologous mesenchymal stem cells for end-stage liver cirrhosis: a meta-analysis based on seven controlled trials. Gastroenterol Res Pract. 2015;2015:1-10.

4. Pan XN, Zheng LQ, Lai XH. Bone marrow-derived mesenchymal stem cell therapy for decompensated liver cirrhosis: a meta-analysis. World J Gastroenterol. 2014;20(38):14051-14057.

5. Qi X, Guo X, Su C. Clinical outcomes of the transplantation of stem cells from various human tissue sources in the management of liver cirrhosis: a systematic review and meta-analysis. Curr Stem Cell Res Ther. 2015;10(2):166-180.

6. Zhang Z, Wang FS. Stem cell therapies for liver failure and cirrhosis. J Hepatol. 2013;59:183-185.

7. Shao CH, Chen SL, Dong TF, et al. Transplantation of bone marrowderived mesenchymal stem cells after regional hepatic irradiation ameliorates thioacetamide-induced liver fibrosis in rats. J Surg Res. 2014; 186(1):408-416.

8. Salama H, Zekri AR, Medhat E, et al. Peripheral vein infusion of autologous mesenchymal stem cells in Egyptian HCV-positive patients with end-stage liver disease. Stem Cell Res Ther. 2014;5(3):70.

9. Jang YO, Kim YJ, Baik SK, et al. Histological improvement following administration of autologous bone marrow-derived mesenchymal stem cells for alcoholic cirrhosis: a pilot study. Liver Int. 2014;34(1): 33-41.
10. Mohamadnejad M, Alimoghaddam K, Bagheri M, et al. Randomized placebo-controlled trial of mesenchymal stem cell transplantation in decompensated cirrhosis. Liver Int. 2013;33(10):1490-1496.

11. Kakinuma S, Tanaka Y, Chinzei R, et al. Human umbilical cord blood as a source of transplantable hepatic progenitor cells. Stem Cells. 2003; 21(2):217-227.

12. Andreone P, Catani L, Margini C, et al. Reinfusion of highly purified $\mathrm{CD} 133+$ bone marrow-derived stem/progenitor cells in patients with end-stage liver disease: a phase I clinical trial. Dig Liver Dis. 2015; 47(12):1059-1066.

13. Burganova GR. [Effectiveness of autologous hematopoietic stem cells transplantation in patients with liver cirrhosis]. Eksp Klin Gastroenterol. 2012;4:91-97. Russian.

14. Mohamadnejad M, Namiri M, Bagheri M, et al. Phase 1 human trial of autologous bone marrow-hematopoietic stem cell transplantation in patients with decompensated cirrhosis. World J Gastroenterol. 2007; 13(24):3359-3363.

15. Zhou C, Yang B, Tian Y, et al. Immunomodulatory effect of human umbilical cord Wharton's jelly-derived mesenchymal stem cells on lymphocytes. Cell Immunol. 2011;272(1):33-38.

16. Womble TA, Green S, Shahaduzzaman M, et al. Monocytes are essential for the neuroprotective effect of human cord blood cells following middle cerebral artery occlusion in rat. Mol Cell Neurosci. 2014;59: $76-84$.

17. Huang L, Liu Y, Lu J, Cerqueira B, Misra V, Duong TQ. Intraarterial transplantation of human umbilical cord blood mononuclear cells in hyperacute stroke improves vascular function. Stem Cell Res Ther. 2017; $8(1): 74$.

18. Sugano M, Yoshida H, Kurobe H, et al. Effects of transplanted human cord blood-mononuclear cells on pulmonary hypertension in immunodeficient mice and their distribution. $J$ Med Invest. 2017;64(1.2):43-49.

19. Kumar A, Prasad M, Jali VP, et al. Bone marrow mononuclear cell therapy in ischaemic stroke: a systematic review. Acta Neurol Scand. 2017; 135(5):496-506.

20. Lou X, Zhao C, Chen H. Unrelated donor umbilical cord blood transplant versus unrelated hematopoietic stem cell transplant in patients with acute leukemia: a meta-analysis and systematic review. Blood Rev. Epub 2017 Nov 15.

21. Lin H, Zhang Z, Shi M, et al. [Prospective controlled trial of safety of human umbilical cord derived-mesenchymal stem cell transplantation in patients with decompensated liver cirrhosis]. Zhonghua Gan Zang Bing Za Zhi. 2012;20:487-491.

22. Zhang Z, Lin H, Shi M, et al. Human umbilical cord mesenchymal stem cells improve liver function and ascites in decompensated liver cirrhosis patients. J Gastroenterol Hepatol. 2012;27(suppl 2):112-120.

23. Zeng X, Zhang Y, Kwong JS, et al. The methodological quality assessment tools for preclinical and clinical studies, systematic review and meta-analysis, and clinical practice guideline: a systematic review. J Evid Based Med. 2015;8(1):2-10.

24. Jackson D, White IR, Riley RD. Quantifying the impact of betweenstudy heterogeneity in multivariate meta-analyses. Stat Med. 2012; 31(29):3805-3820.

25. DerSimonian R, Laird N. Meta-analysis in clinical trials. Control Clin Trials. 1986;7(3):177-188.

26. Li WG, Cai JL, Zhang JL, et al. Efficacy of umbilical cord blood stem cells in treatment of decompensated hepatitis B cirrhosis. Chin J Prac Med. 2013;40:112-114.

27. Li YY, Zhang DF. A feasibility study on treating cirrhosis of hepatolenticular degeneration type by umbilical blood stem cell transplantation plus the Danhong injection. Clin J Chin Med. 2016;8:20-22.

28. Tan YW, Chen L, Zhu MQ, Zhou XB, Mao JZ, Li LD. The effect of transplantation of human umbilical cord blood stem cell on decompensated cirrhosis. Chin Hepatol. 2012;17:542-545.

29. Wang F, Zhang J, Feng SX, Song HT. Umbilical cord blood stem cell transplantation via the portal vein: analysis of the curative rate in 30 patients with decompensated liver cirrhosis. J Clin Hepatol. 2012; $28: 824-827$ 
30. Wang KJ, Luo XH, Sun HT, Wang F, Bao JT. Effect of liver volume and liver hemodynamics of human umbilical cord blood stem cell transplantation on decompensated cirrhosis. Chin J Difficult Complicated Cases. 2014;13:1126-1133.

31. Zhang S, Yan BY, Tong LX, et al. Therapeutic effect of the umbilical blood stem cell transplantation on the treatment of hepatitis B liver cirrhosis. J Prac Med. 2015;31:3162-3165.

32. Zhou XL, Xie S, Hou QK, Li C. Clinical research on umbilical cord blood stem cells transplantation for hepatitis B liver cirrhosis at discompensation stage. J Chengdu Med Coll. 2013;8:571-574.

33. Zhou XR, Wang F, Yun SH, et al. Intrahepatic transplantation of umbilical cord blood stem cells in treatment of patients with decompensated primary biliary cirrhosis. J Prac Hepatol. 2016;19:219-220.

34. Zhou XR, Wang F, Yun SH, et al. Transplantation of human umbilical cord blood stem cells in treatment of patients with decompensated alcoholic liver cirrhosis. J Prac Hepatol. 2017;20:232-233.

35. Zhu YH, Han DZ. Clinical observation of the effect of umbilical cord blood stem cell transplantation in treatment of decompensated cirrhosis. Chin J Postgraduates Med. 2014;37:15-17.

36. Yin L, Zhu Y, Yang J, et al. Adipose tissue-derived mesenchymal stem cells differentiated into hepatocyte-like cells in vivo and in vitro. Mol Med Rep. 2015;11(3):1722-1732.

37. Al Ghrbawy NM, Afify RA, Dyaa N, El Sayed AA. Differentiation of bone marrow: derived mesenchymal stem cells into hepatocyte-like cells. Indian J Hematol Blood Transfus. 2016;32(3):276-283.

38. Cho KA, Ju SY, Cho SJ, et al. Mesenchymal stem cells showed the highest potential for the regeneration of injured liver tissue compared with other subpopulations of the bone marrow. Cell Biol Int. 2009; 33(7):772-777.

39. van Poll D, Parekkadan B, Cho CH, et al. Mesenchymal stem cellderived molecules directly modulate hepatocellular death and regeneration in vitro and in vivo. Hepatology. 2008;47(5):1634-1643.

40. Adas G, Koc B, Adas M, et al. Effects of mesenchymal stem cells and VEGF on liver regeneration following major resection. Langenbeck Arch Surg. 2016;401(5):725-740.

41. Parekkadan B, van Poll D, Megeed Z, et al. Immunomodulation of activated hepatic stellate cells by mesenchymal stem cells. Biochem Biophys Res Commun. 2007;363(2):247-252.
42. Zhang B, Inagaki M, Jiang B, et al. Effects of bone marrow and hepatocyte transplantation on liver injury. J Surg Res. 2009;157(1):71-80.

43. Chang YJ, Liu JW, Lin PC, et al. Mesenchymal stem cells facilitate recovery from chemically induced liver damage and decrease liver fibrosis. Life Sci. 2009;85(13-14):517-525.

44. Higashiyama R, Inagaki Y, Hong YY, et al. Bone marrow-derived cells express matrix metalloproteinases and contribute to regression of liver fibrosis in mice. Hepatology. 2007;45(1):213-222.

45. Pan RL, Wang P, Xiang LX, Shao JZ. Delta-like 1 serves as a new target and contributor to liver fibrosis down-regulated by mesenchymal stem cell transplantation. J Biol Chem. 2011;286(14):12340-12348.

46. Chen S, Xu L, Lin N, Pan W, Hu K, Xu R. Activation of Notch1 signaling by marrow-derived mesenchymal stem cells through cell-cell contact inhibits proliferation of hepatic stellate cells. Life Sci. 2011; 89(25-26):975-981.

47. Moon YJ, Yoon HH, Lee MW, et al. Multipotent progenitor cells derived from human umbilical cord blood can differentiate into hepatocyte-like cells in a liver injury rat model. Transplant Proc. 2009;41(10):4357-4360.

48. Nakamura $T$, Tsutsumi $V$, Torimura $T$, et al. Human peripheral blood CD34-positive cells enhance therapeutic regeneration of chronically injured liver in nude rats. J Cell Physiol. 2012;227(4):1538-1552.

49. Rocha V. Umbilical cord blood cells from unrelated donor as an alternative source of hematopoietic stem cells for transplantation in children and adults. Semin Hematol. 2016;53(4):237-245.

50. Pinana JL, Sanz J, Esquirol A, et al. Umbilical cord blood transplantation in adults with advanced Hodgkin's disease: high incidence of post-transplant lymphoproliferative disease. Eur J Haematol. 2016; 96(2):128-135

51. Kang M, Min K, Jang J, et al. Involvement of immune responses in the efficacy of cord blood cell therapy for cerebral palsy. Stem Cells Dev. 2015;24(19):2259-2268.

52. Kong D, Zhuang X, Wang D, et al. Umbilical cord mesenchymal stem cell transfusion ameliorated hyperglycemia in patients with type 2 diabetes mellitus. Clin Lab. 2014;60(12):1969-1976. 


\section{Supplementary materials}

A

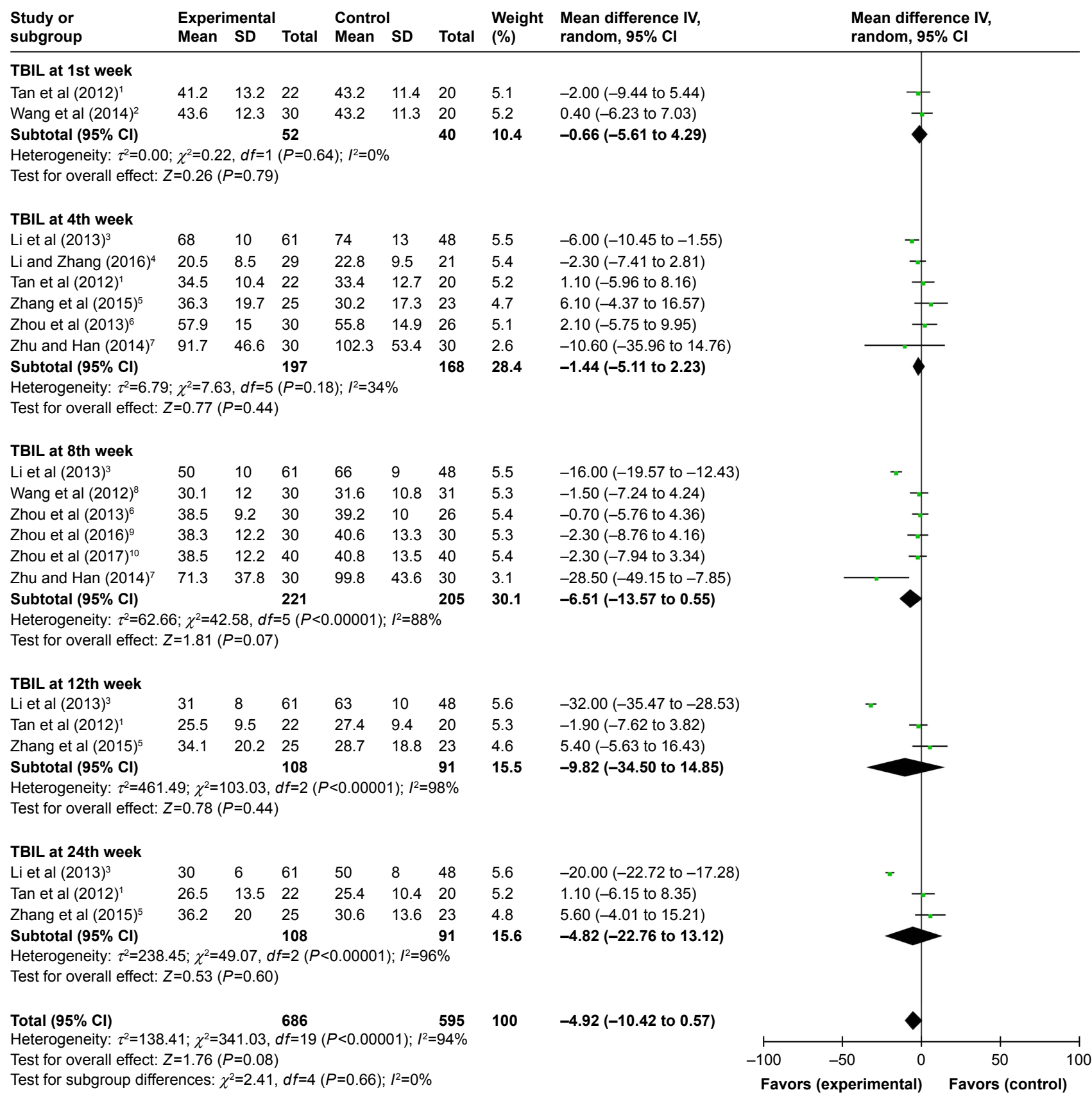

Figure SI (Continued) 
B

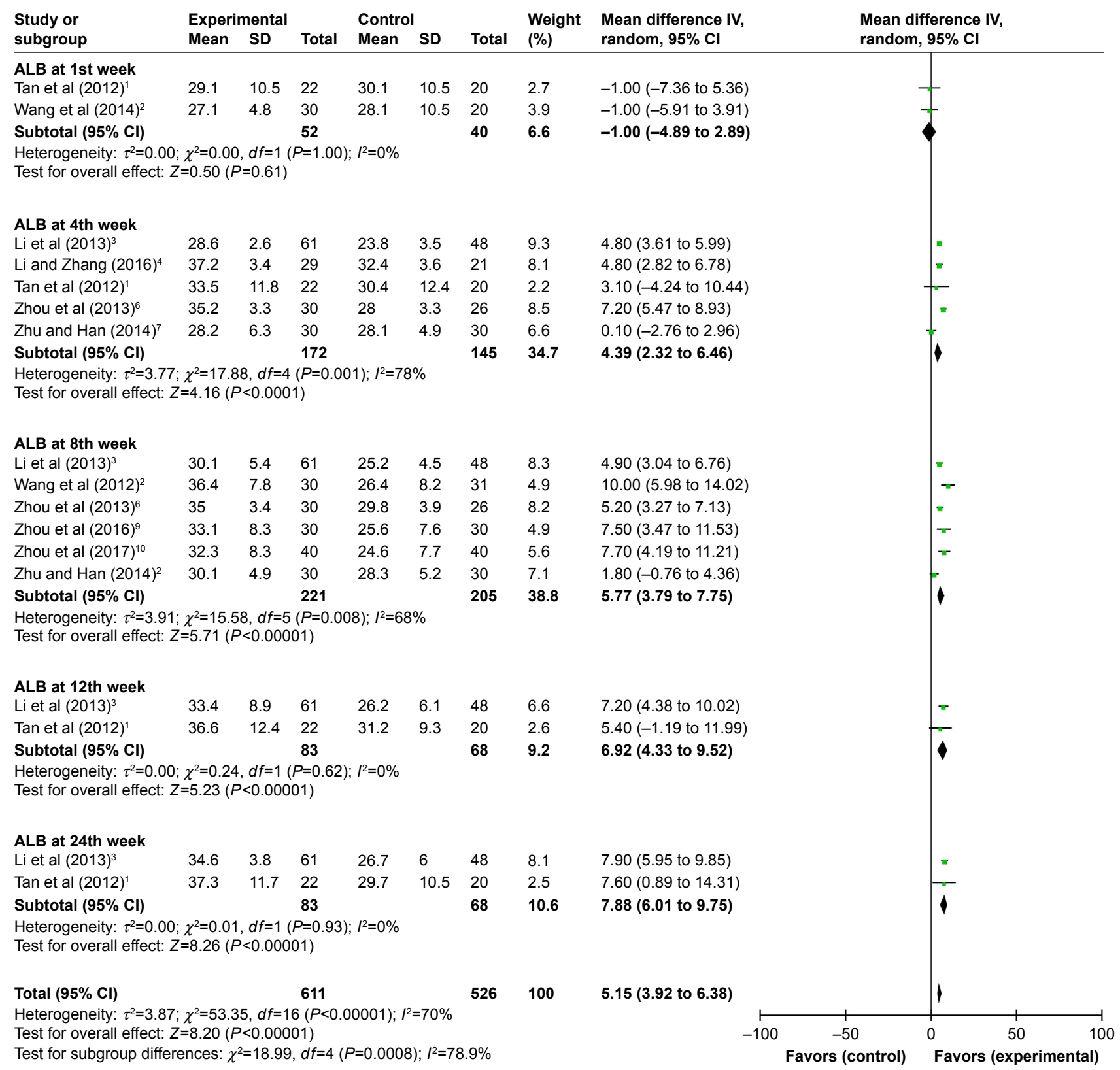

Figure SI (Continued) 
C

Study or Experimental Control Weight Mean difference IV, Mean difference IV,

\begin{tabular}{lllllllll}
\hline ALT at 1st week & & & & & & & & \\
Tan et al $(2012)^{1}$ & 212.4 & 67.4 & 22 & 221.3 & 86.4 & 20 & 0.4 & $-8.90(-56.09$ to 38.29$)$ \\
Wang et al $(2014)^{2}$ & 52.1 & 9.8 & 30 & 50.2 & 9.9 & 20 & 6.2 & $1.90(-3.68$ to 7.48$)$
\end{tabular}

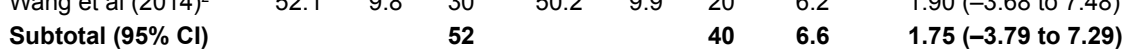

Heterogeneity: $\tau^{2}=0.00 ; \chi^{2}=0.20, d f=1(P=0.66) ; I^{2}=0 \%$

Test for overall effect: $Z=0.62(P=0.54)$

ALT at 4th week

Li et al $(2013)^{3}$

Li and Zhang (2016)

$\begin{array}{lll}66 & 15 & 61\end{array}$

$\begin{array}{lll}39.8 & 25.2 \quad 29\end{array}$

$\begin{array}{lll}67.2 & 23.5 & 22\end{array}$

$\begin{array}{lll}31.5 & 16.7 & 25\end{array}$

Zhang et al (2015)

Zhou et al (2013) ${ }^{6}$

Zhu and Han (2014)

Subtotal $(95 \% \mathrm{Cl})$

$\begin{array}{lll}37.8 & 13.7 & 30\end{array}$

18.330

197

$\begin{array}{lll}73 & 21 & 48\end{array}$

$\begin{array}{lll}49.5 & 42.9 \quad 21\end{array}$

$87.3 \quad 32.4 \quad 20$

$\begin{array}{lll}31 & 12.9 & 23\end{array}$

$\begin{array}{lll}51.6 & 14.2 \quad 26\end{array}$

$48.2 \quad 12.9 \quad 30$

$12.9 \quad 30$

Heterogeneity: $\tau^{2}=89.23 ; \chi^{2}=24.85, d f=5(P=0.0001) ; I^{2}=80 \%$

Test for overall effect: $Z=1.21(P=0.23)$

\section{ALT at 8th week}

Li et al (2013) ${ }^{3}$

Wang et al $(2012)^{8}$

Zhou et al $(2013)^{6}$

Zhou et al $(2016)^{9}$

Zhou et al $(2017)^{10}$

$\begin{array}{lll}46 & 9 & 61 \\ 46.2 & 14.6 & 30\end{array}$

$\begin{array}{lll}46.9 & 14 & 30\end{array}$

$\begin{array}{lll}36.3 & 13.5 \quad 30\end{array}$

$\begin{array}{lll}37.3 & 13.5 \quad 40\end{array}$

$\begin{array}{lll}55.6 & 19.3 \quad 30\end{array}$

221

$\begin{array}{llll}52 & 8 & 48 & 7.2\end{array}$

$\begin{array}{llll}44.8 & 15.1 & 31 & 5.3\end{array}$

$\begin{array}{llll}49.9 & 14.3 & 26 & 5.4\end{array}$

$\begin{array}{llll}39.2 & 13.3 & 30 & 5.7\end{array}$

$\begin{array}{llll}39.4 & 13.3 & 40 & 6.1\end{array}$

$\begin{array}{llll}49.1 & 16.8 & 30 & 4.6\end{array}$

Subtotal $(95 \% \mathrm{CI})$

Heterogeneity: $\tau^{2}=18.29 ; \chi^{2}=14.64, d f=5(P=0.01) ; I^{2}=66 \%$

Test for overall effect: $Z=1.45(P=0.15)$

ALT at 12th week

Li et al $(2013)^{3}$

Tan et al (2012) 1

$\begin{array}{llllll}36 & 7 & 61 & 50 & 15 & 48\end{array}$

$\begin{array}{llllll}46.3 & 12.5 & 22 & 48.2 & 13.9 & 20\end{array}$

Zhang et al $(2015)^{5}$

Subtotal $(95 \% \mathrm{Cl})$

Heterogeneity: $\tau^{2}=72.55 ; \chi^{2}=13.23, d f=2(P=0.001) ; l^{2}=85 \%$

Test for overall effect: $Z=0.97(P=0.33)$

ALT at 24th week

Li et al $(2013)^{3}$

Tan et al (2012) ${ }^{1}$

Zhang et al $(2015)^{5}$

Subtotal $(95 \% \mathrm{Cl})$

$\begin{array}{lll}34 & 6 & 61 \\ 37.4 & 12.3 & 22\end{array}$

$\begin{array}{lll}37.4 & 12.3 \quad 22\end{array}$

42

41.4

29.7

13.125

108

11.423

91

Heterogeneity: $\tau^{2}=24.88 ; \chi^{2}=7.22, d f=2(P=0.03) ; I^{2}=72 \%$

Test for overall effect: $Z=0.99(P=0.32)$

Total $(95 \% \mathrm{Cl})$

686

6.7

5.1

4.7

16.4

$-14.00(-18.59$ to -9.41$)$

$-1.90(-9.92$ to 6.12$)$

$1.90(-7.07$ to 10.87$)$

$-5.20(-15.72$ to 5.32$)$

$1.40(-6.05$ to 8.85$)$

$-13.00(-20.44$ to -5.56$)$

-2.90 (-9.68 to 3.88$)$

-2.10 (-7.97 to 3.77$)$

$6.50(-2.66$ to 15.66$)$

$-3.20(-7.55$ to 1.14$)$

Heterogeneity: $\tau^{2}=31.16 ; \chi^{2}=70.60, d f=19(P<0.00001) ; l^{2}=73 \%$

Test for overall effect: $Z=2.36(P=0.02)$

Test for subgroup differences: $\chi^{2}=3.09, d f=4(P=0.54) ; I^{2}=0 \%$ random, $95 \% \mathrm{Cl}$

Figure SI (Continued) 
D

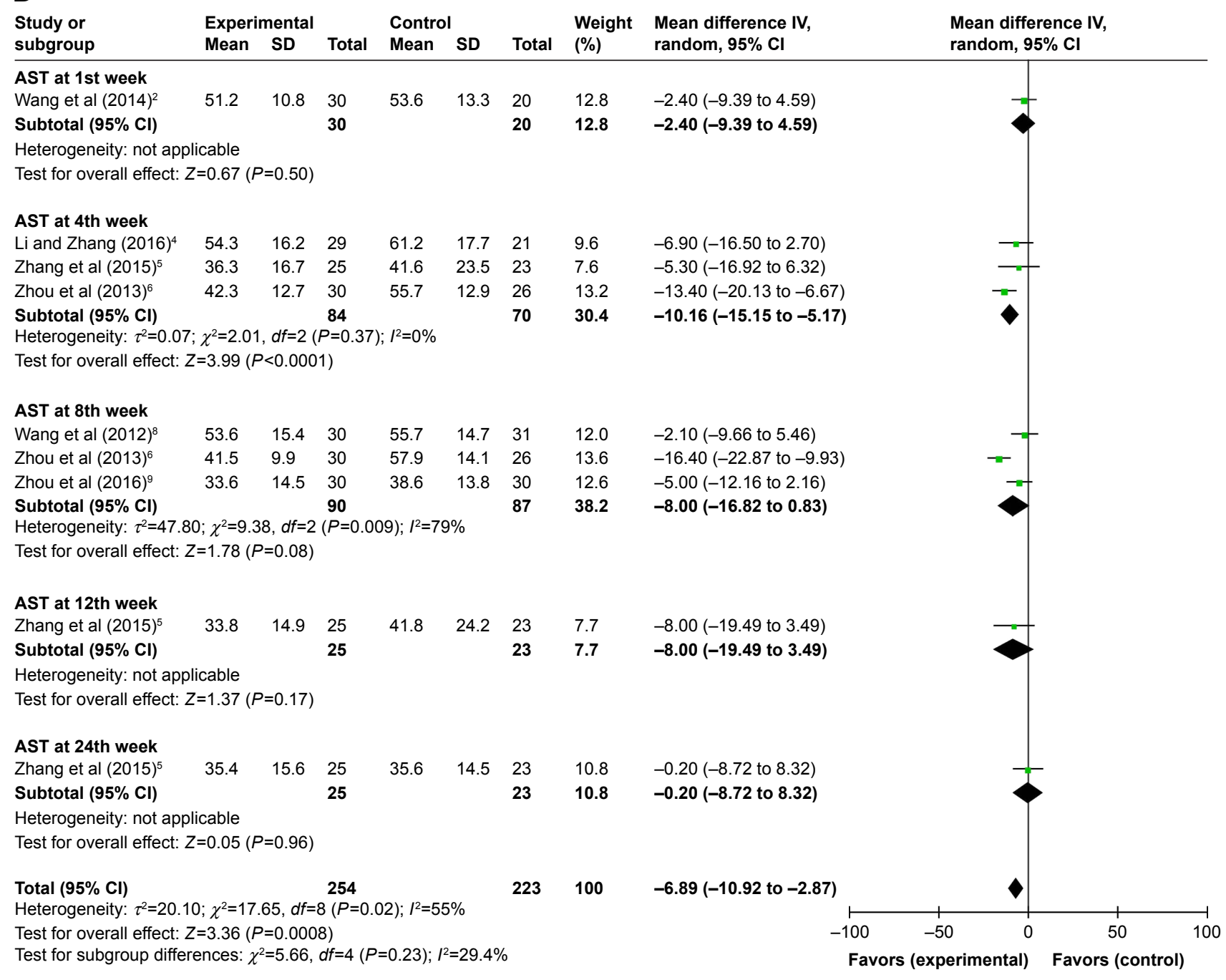

Figure SI (Continued) 
E

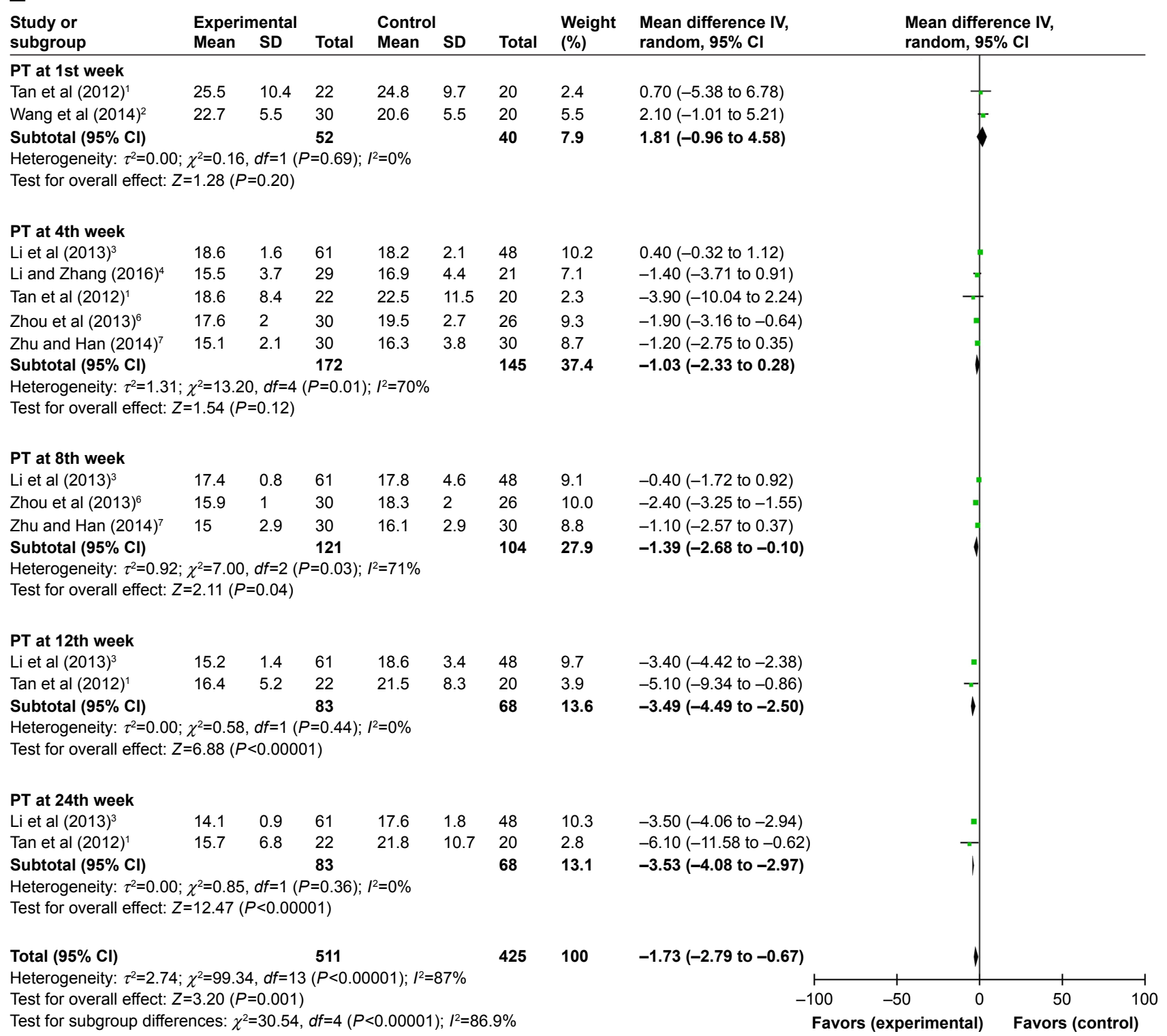

Figure SI (Continued) 


\section{F}

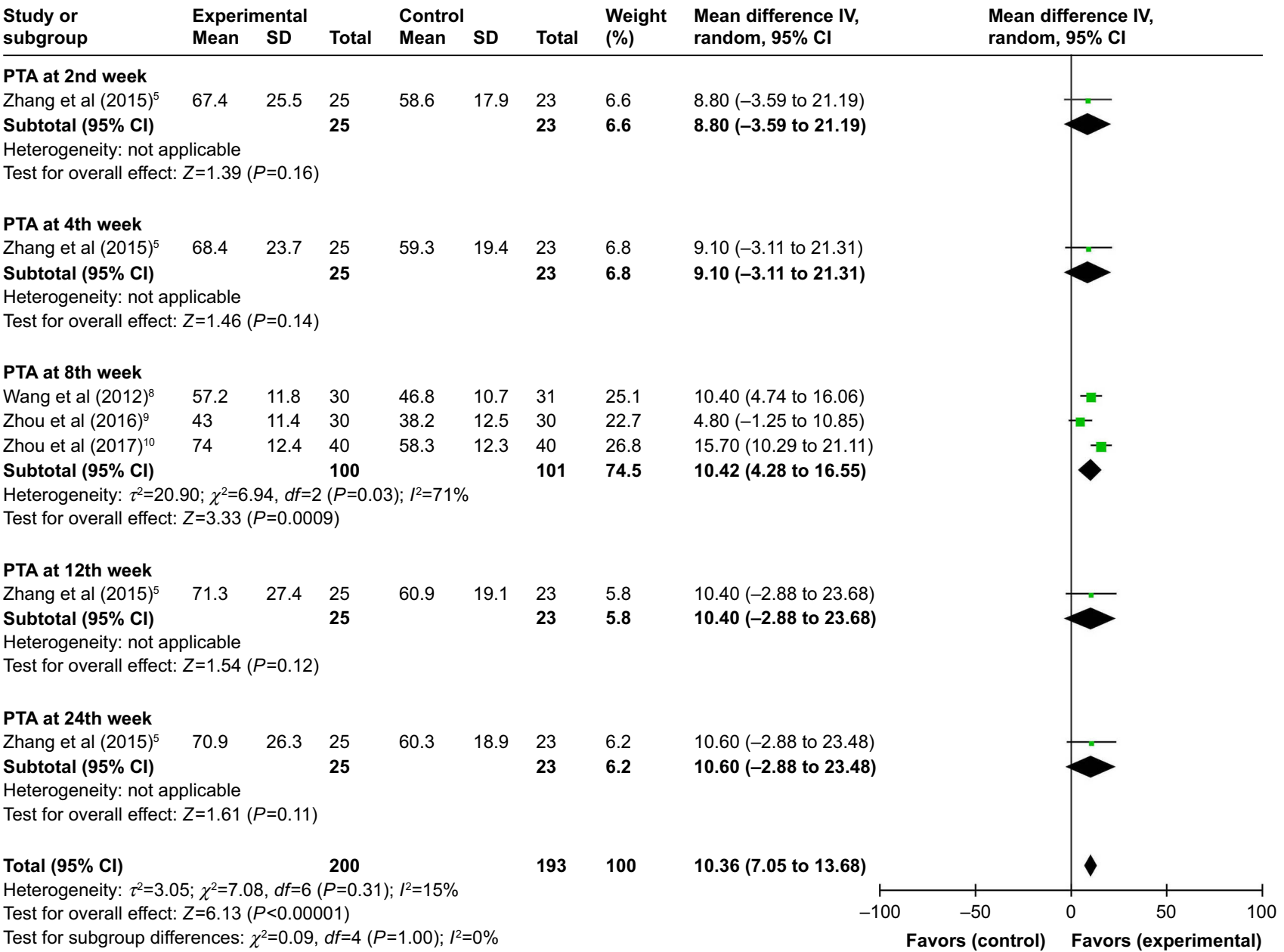

Figure SI Forest plot of the comparison of TBIL (A), ALB (B), ALT (C), AST (D), PT (E) and PTA (F) between the experimental and control groups. Notes: Control group, RST alone group; experimental group, RST plus USCs therapy.

Abbreviations: IV, inverse variance method; TBIL, total bilirubin; ALB, albumin; ALT, alanine aminotransferase; AST, aspartate aminotransferase; PT, prothrombin time; PTA, prothrombin activity; USCs, umbilical cord blood stem cells; RST, routine supportive treatment. 

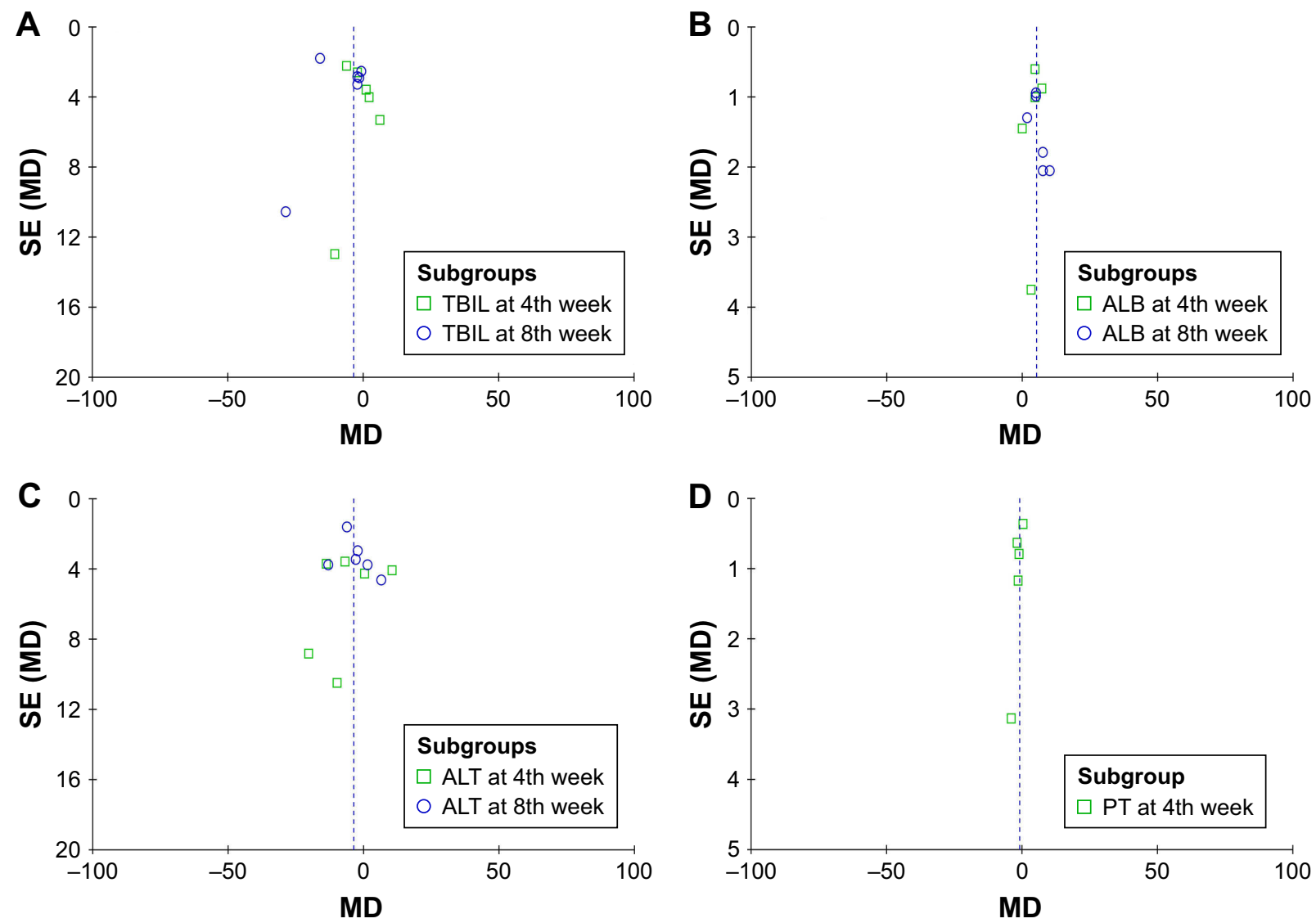

Figure S2 Funnel plot of percentage of total bilirubin (TBIL, A), albumin (ALB, B), alanine aminotransferase (ALT, C) and prothrombin time (PT, D) between the experimental and control groups.

Notes: Subgroup analyses were conducted in parameters discussed in $>6$ papers. Control group, routine supportive therapy alone group; experimental group, RST plus umbilical cord blood stem cell therapy. 
Table SI Subgroup analyses of TBIL, ALB, ALT and PT between the experimental and control groups

\begin{tabular}{|c|c|c|c|c|c|c|c|c|c|c|}
\hline \multirow[t]{2}{*}{ Parameters } & \multirow{2}{*}{$\begin{array}{l}\text { Time point } \\
\text { (after } \\
\text { therapy) }\end{array}$} & \multirow{2}{*}{$\begin{array}{l}\text { Factors at } \\
\text { study level }\end{array}$} & \multirow{2}{*}{$\begin{array}{l}\text { Exp group } \\
\text { No of } \\
\text { patients }\end{array}$} & \multirow{2}{*}{$\begin{array}{l}\text { Con group } \\
\text { No of } \\
\text { patients }\end{array}$} & \multirow{2}{*}{$\begin{array}{l}\text { Analysis } \\
\text { method }\end{array}$} & \multicolumn{2}{|c|}{ Heterogeneity } & \multirow[t]{2}{*}{ OR } & \multirow[t]{2}{*}{$95 \% \mathrm{Cl}$} & \multirow[t]{2}{*}{$P$-value } \\
\hline & & & & & & $I^{2}(\%)$ & $P$-value & & & \\
\hline \multirow[t]{6}{*}{ TBIL } & 4th week & $\mathrm{CN}>1 \times 10^{8}$ & 113 & 94 & Random & 57 & 0.10 & -1.66 & -7.24 to 3.93 & 0.56 \\
\hline & & $\mathrm{CN}<\mathrm{I} \times 10^{8}$ & 84 & 74 & Random & 22 & 0.28 & -0.47 & -6.73 to 5.79 & 0.88 \\
\hline & & Hepatic artery & 82 & 76 & Random & 0 & 0.64 & 1.05 & -4.09 to 6.19 & 0.69 \\
\hline & & Intravenous & 115 & 92 & Random & 57 & 0.10 & -2.35 & -7.70 to 3.01 & 0.39 \\
\hline & 8th week & $\mathrm{CN}>1 \times 10^{8}$ & 91 & 74 & Random & 96 & $<0.00001$ & -8.46 & -23.45 to 6.53 & 0.27 \\
\hline & & $\mathrm{CN}<\mathrm{I} \times 10^{8}$ & 130 & $|3|$ & Random & 52 & 0.10 & -3.56 & -8.84 to $|.7|$ & 0.19 \\
\hline \multirow[t]{6}{*}{ ALB } & 4th week & $\mathrm{CN}>1 \times 10^{8}$ & 113 & 94 & Random & 63 & 0.07 & 5.70 & 3.62 to 7.78 & $<0.00001$ \\
\hline & & $\mathrm{CN}<\mathrm{I} \times 10^{8}$ & 59 & 51 & Random & 86 & 0.008 & 2.57 & -2.03 to 7.17 & 0.27 \\
\hline & & Hepatic artery & 82 & 76 & Random & 89 & 0.0001 & 3.60 & -1.95 to 9.16 & 0.20 \\
\hline & & Intravenous & 90 & 69 & Random & 0 & 1.00 & 4.80 & 3.78 to 5.82 & $<0.00001$ \\
\hline & 8th week & $\mathrm{CN}>1 \times 10^{8}$ & 91 & 74 & Random & 0 & 0.83 & 5.04 & 3.71 to 6.38 & $<0.00001$ \\
\hline & & $\mathrm{CN}<\mathrm{I} \times 10^{8}$ & 130 & 131 & Random & 80 & 0.002 & 6.56 & 2.65 to 10.48 & 0.001 \\
\hline \multirow[t]{6}{*}{ ALT } & 4th week & $\mathrm{CN}>1 \times 10^{8}$ & 113 & 94 & Random & 30 & 0.24 & -11.45 & -17.68 to -5.22 & 0.0003 \\
\hline & & $\mathrm{CN}<\mathrm{I} \times 10^{8}$ & 84 & 74 & Random & 59 & 0.09 & 3.08 & -6.63 to 12.79 & 0.53 \\
\hline & & Hepatic artery & 82 & 76 & Random & 91 & $<0.0001$ & -7.01 & -26.09 to 12.06 & 0.47 \\
\hline & & Intravenous & 115 & 92 & Random & 4 & 0.35 & -4.27 & -9.67 to 1.13 & 0.12 \\
\hline & 8th week & $\mathrm{CN}>1 \times 10^{8}$ & 91 & 74 & Random & 65 & 0.09 & -8.66 & -15.32 to -2.00 & 0.01 \\
\hline & & $\mathrm{CN}<\mathrm{I} \times 10^{8}$ & 130 & 131 & Random & 8 & 0.36 & -0.20 & -3.88 to 3.48 & 0.91 \\
\hline \multirow[t]{4}{*}{ PT } & 4th week & $\mathrm{CN}>1 \times 10^{8}$ & 113 & 94 & Random & 82 & 0.004 & -1.00 & -3.14 to 1.14 & 0.36 \\
\hline & & $\mathrm{CN}<\mathrm{I} \times 10^{8}$ & 59 & 51 & Random & 0 & 0.89 & -1.26 & -2.55 to 0.03 & 0.06 \\
\hline & & Hepatic artery & 82 & 76 & Random & 0 & 0.61 & -1.68 & -2.65 to -0.7 I & 0.0007 \\
\hline & & Intravenous & 90 & 69 & Random & 53 & 0.15 & -0.15 & -1.78 to 1.48 & 0.86 \\
\hline
\end{tabular}

Notes: Subgroup analyses were conducted in parameters discussed in $>6$ papers. Control group, RST alone group; experimental group, RST plus USCs therapy. Abbreviations: Exp, experimental; Con, control; TBIL, total bilirubin; ALB, albumin; ALT, alanine aminotransferase; PT, prothrombin time; OR, odds ratio; RST, routine supportive therapy; USCs, umbilical cord blood stem cells.

\section{References}

1. Tan YW, Chen L, Zhu MQ, Zhou XB, Mao JZ, Li LD. The effect of transplantation of human umbilical cord blood stem cell on decompensated cirrhosis. Chin Hepatol. 2012;17:542-545.

2. Wang KJ, Luo XH, Sun HT, Wang F, Bao JT. Effect of liver volume and liver hemodynamics of human umbilical cord blood stem cell transplantation on decompensated cirrhosis. Chin J Difficult Complicated Cases. 2014;13:1126-1133.

3. Li WG, Cai JL, Zhang JL, et al. Efficacy of umbilical cord blood stem cells in treatment of decompensated hepatitis B cirrhosis. Chin J Prac Med. 2013;40:112-114.

4. Li YY, Zhang DF. A feasibility study on treating cirrhosis of hepatolenticular degeneration type by umbilical blood stem cell transplantation plus the Danhong injection. Clin J Chin Med. 2016;8:20-22.

5. Zhang S, Yan BY, Tong LX, et al. Therapeutic effect of the umbilical blood stem cell transplantation on the treatment of hepatitis B liver cirrhosis. J Prac Med. 2015;31:3162-3165.
6. Zhou XL, Xie S, Hou QK, Li C. Clinical research on umbilical cord blood stem cells transplantation for hepatitis B liver cirrhosis at discompensation stage. J Chengdu Med Coll. 2013;8:571-574.

7. Zhu YH, Han DZ. Clinical observation of the effect of umbilical cord blood stem cell transplantation in treatment of decompensated cirrhosis. Chin J Postgraduates Med. 2014;37:15-17.

8. Wang F, Zhang J, Feng SX, Song HT. Umbilical cord blood stem cell transplantation via the portal vein: analysis of the curative rate in 30 patients with decompensated liver cirrhosis. J Clin Hepatol. 2012; 28:824-827.

9. Zhou XR, Wang F, Yun SH, et al. Intrahepatic transplantation of umbilical cord blood stem cells in treatment of patients with decompensated primary biliary cirrhosis. J Prac Hepatol. 2016;19:219-220.

10. Zhou XR, Wang F, Yun SH, et al. Transplantation of human umbilical cord blood stem cells in treatment of patients with decompensated alcoholic liver cirrhosis. J Prac Hepatol. 2017;20:232-233.
Therapeutics and Clinical Risk Management

\section{Publish your work in this journal}

Therapeutics and Clinical Risk Management is an international, peerreviewed journal of clinical therapeutics and risk management, focusing on concise rapid reporting of clinical studies in all therapeutic areas, outcomes, safety, and programs for the effective, safe, and sustained use of medicines. This journal is indexed on PubMed Central, CAS,

\section{Dovepress}

EMBase, Scopus and the Elsevier Bibliographic databases. The manuscript management system is completely online and includes a very quick and fair peer-review system, which is all easy to use. Visit $\mathrm{http}: / /$ www.dovepress.com/testimonials.php to read real quotes from published authors. 